\author{
Federal Reserve Bank of Dallas \\ Globalization and Monetary Policy Institute \\ Working Paper No. 257 \\ http://www.dallasfed.org/assets/documents/institute/wpapers/2015/0257.pdf
}

\title{
Beggar Thy Neighbor or Beggar Thy Domestic Firms? Evidence from 2000-2011 Chinese Customs Data ${ }^{*}$
}

Rasmus Fatum

University of Alberta

Jiadong Tong

Nankai University

\author{
Runjuan Liu \\ University of Alberta \\ Jiayun Xu \\ Tsinghua University
}

November 2015

\begin{abstract}
The premise of beggar-thy-neighbor policies and currency wars is that currency depreciations lead to export growth. This premise, however, is far from validated as the existing economic literature largely either fails to find significant trade flow effects of currency fluctuations or finds that these effects are only minor. We revisit the question of whether currency fluctuations are systematically associated with trade flows using rich and unique firm level Chinese customs data on China-US trade over the 2000 to 2011 period that allows us to consider firm involvement in processing trade and firm dynamics in both export and import markets. Our firm-level based estimation of trade elasticities suggest that the China-US trade balance strongly responds to changes in the CNY/USD rate. This finding is particularly pronounced when we distinguish between ordinary and processing firms. Our results thus suggest that the influence of exchange rates on trade flows is stronger than previously thought and add insights to the policy debate on beggar-thy-neighbor policies and currency wars by, at least in principle, validating the underlying premise of such policies.
\end{abstract}

JEL codes: F14, F31, F41

\footnotetext{
* Rasmus Fatum, Alberta School of Business, University of Alberta, Edmonton, Alberta, T6G 2R6, Canada. 780-492-3951. rasmus.fatum@ualberta.ca. Runjuan Liu, University of Alberta, 3-21C Business, Edmonton, Alberta, Canada T6G 2R6. 780-492-0334. runjuan.liu@ualberta.ca. Jiadong Tong, School of Economics, Nankai University. tongjd@nankai.edu.cn. Jiayun Xu, School of Public Policy \& Management, Tsinghua University. xujiayun321@163.com. Fatum is also Research Associate at the Federal Reserve Bank of Dallas and member of the Economic Policy Research Unit (EPRU) at the University of Copenhagen. Fatum gratefully acknowledges financial support from a Foote Professorship in International Business. Tong gratefully acknowledges financial support from the National Social Science Foundation of China. The views in this paper are those of the authors and do not necessarily reflect the views of the Federal Reserve Bank of Dallas or the Federal Reserve System.
} 


\section{Introduction}

The generally slow growth rates in the aftermath of the global financial crisis have prompted several countries to pursue economic policies that are likely to depreciate the relative value of their respective domestic currencies. For example, several central banks have pursued various forms of largely uncoordinated expansionary monetary policies, e.g. the massive quantitative easing undertaken by the US Federal Reserve, in attempts to stimulate growth. These policies have been criticized for being beggarthy-neighbor policies aimed at stimulating export-driven growth at the expense of trading partners and, as such, have raised fears of igniting currency wars. ${ }^{1}$ Interestingly, however, is the fact that the underlying premise of beggar-thy-neighbor policies and currency wars, namely that currency depreciations lead to export growth, is not well-supported in the existing economic literature as the literature largely either fails to find statistically significant trade flow effects of currency fluctuations or finds that these effects are only minor and economically insignificant. ${ }^{2}$

Clearly, the monetary policy undertakings in the aftermath of the global financial crisis have generated a heated debate about whether or not some countries are pursuing more or less clandestine beggar thy neighbor exchange rate policies, yet surprisingly little has been put forward in regards to whether generating export-led growth via a policy induced depreciation of the domestic currency is actually realistic and feasible. Put differently, the underlying mechanism of a beneficial beggar-thyneighbor policy, or the potentially advantageous outcome of engaging in a currency war, relies on a traditional textbook view in which a lower relative value of domestic currency will make domestic exporters more competitive and as a result will improve the trade balance (e.g. Marshall, 1923, and Lerner, 1944) even though there is no clear evidence of a systematic link between exchange rates and

\footnotetext{
${ }^{1}$ The currency depreciating policies that may amount to covert beggar thy neighbor exchange rate policies have prompted widespread criticism. For example, then Brazilian Finance Minister Mantega in September 2010 famously accused the US of engaging in a "currency war". In January 2013, prompted by Japan's contemplation of further monetary easing, a similar criticism was launched by an official from the Central Bank of Russia, Aleksey Ulyukaev, who also warned of "currency wars". More recently, Roubini (2015) argued that "the US has effectively joined the "currency war" to prevent further dollar appreciation."

${ }^{2}$ For example, Thorbecke and Smith (2010) find a low exchange rate elasticity of exports when analyzing Chinese aggregate trade data. See also Park (2005), Thorbecke (2006), and Cheung, Chinn, and Qian (2012) for related contributions to the traditional trade literature.
} 
export growth in the empirical economic literature. Moreover, in the current context of a highly globalized world where exported goods often contain processed imports, the net-effect of currency movements on exports and imports in particular, and trade balance and economic growth in general, is less than obvious. This is because the positive exchange rate effects experienced by pure exporting firms may be more than off-set by the negative exchange rate effects experienced by importing as well as processing exporting firms leading to a possible scenario of beggar-thy-neighbor policies resulting in a net-effect of "beggar-thy-domestic firms". As it stands, most of the existing empirical evidence on the effect of exchanges rate changes on the trade balance use aggregate trade data and find only minor effects of exchange rate changes on trade. More recently, however, studies using firm-level data to address the "exchange rate disconnect" puzzle has pointed out that the low aggregate exchange rate elasticity result may stem from aggregation bias (e.g. Dekle, Jeong, and Ryoo, 2009). That is, estimations using aggregate data may be biased because aggregate data neglect the heterogeneous firm level responses to exchange rate changes. ${ }^{3}$

To address whether the underlying premise of beggar-thy-neighbor policies is valid and, more broadly, to bring new insights to the issue of whether exchange rate changes systematically influence trade flows we provide a systematic empirical analysis of the impact of exchange rate changes on the aggregate trade balance using unique Chinese firm-level data that allows us to bring the firm to the center of our analysis. First, following the standard decomposition method (e.g. Bernard, Jensen, Redding, and Schott, 2009, and Tang and Zhang, 2012), we decompose aggregate trade balance changes into firm-level outcomes: the changes of exports and imports of continuing firms, and the changes of exports and imports contributed by entry and exit firms. We then examine how exchange rate changes influence these firmlevel outcomes, respectively. Second, facilitated by our detailed firm-level trade data, we distinguish

\footnotetext{
${ }^{3}$ Berman, Martin, and Mayer (2012) analyze the heterogeneous reaction of exporters to real exchange rate changes using a rich French firm-level data set. They find that high-performance firms react to domestic currency depreciation by increasing significantly more their markup and by increasing less their export volume, and claim that the behavior of heterogeneous pricing-to-market may partly explain the seemingly weak impact of exchange rate movements on aggregate exports. Amit, Itskhoki, and Konings (2014) use Belgian firm-product-level data to show that large exporters are simultaneously large importers and that this pattern is essential for understanding the low aggregate exchange rate pass-through.
} 
between ordinary and processing firms depending on the share of processing trade transactions over total trade values and examine whether different types of firms react differently to exchange rate changes. Finally, we use these firm-level estimates of exports and imports elasticities along with estimates of the impact of exchange rate changes on firm entry and exit to provide a quantification of the impact of exchange rate changes on the aggregate China-US trade balance.

The foundation of our study is a rich and unique Chinese Customs firm-level data set that covers the universe of Chinese trade transactions with the US over the 2000 to 2011 period. This data set and sample period enable us to focus on the effect of the CNY revaluation on the China-US trade balance. China and the China-US trade balance provide an ideal setting for examining the impact of exchange rate changes on the trade balance for several reasons. First, The China-US trade balance plays a major role in the global imbalance debate, thus an empirical analysis of how CNY revaluation influences the China-US trade balance may provide important policy implications in regards to how to address global imbalances. ${ }^{4}$ Second, China undertook a major exchange rate reform in 2005 when a fixed exchange rate regime was replaced by a managed float. Since then, the CNY has exhibited significant appreciation, i.e. the CNY appreciated by 22 percent against the USD in nominal terms from the beginning of 2005 to the end of 2011. This large appreciation of the CNY provides us with the exchange rate variation necessary for assessing the impact of exchange rate changes on the China-US trade balance. Third, processing trade has been a prominent feature of Chinese trade, accounting for about $60 \%$ of Chinese exports in recent years (Fernandes and Tang, 2012). ${ }^{5}$ The larger the extent that the exports of a firm stem from imported inputs, the more muted the effect of a given exchange rate movement is likely to be on the export value of a firm (and, similarly, if the imported inputs of a firm are used to produce exports, exchange rate movements

\footnotetext{
${ }^{4}$ Since the economic reform and transition towards a market based economy, China has experienced rapid export growth, especially vis-à-vis the US. The Chinese trade surplus accumulation began in 1985 and in 2011 the USChina trade deficit in goods reached roughly USD 300 billion according to the US Bureau of Economic Analysis. Some economists and policymakers propose that China should adjust its exchange rate policy to alleviate the imbalances between China and US (e.g. Krugman, 2010). However, according to the results of the existing empirical trade literature is far from clear is an appreciation of the CNY would have mitigated the China-US trade imbalances. As our study will suggests, whether exchange rate manipulation can address trade imbalances depends on the behavior of, in this context, Chinese micro trading firms and how they respond to exchange rate changes.

${ }^{5}$ Processing trade is a process in which a domestic firm obtains intermediate inputs from abroad and after local processing exports the value-added final goods (see, for example, Feenstra and Hanson, 2005, and Yu, 2015).
} 
should have a muted impact on import value as well). Our data allows us to explicitly consider in our empirical analysis this very important aspect of the firm and, as it turns out, show that it matters significantly for how firms respond to exchange rate movements and, in turn, how exchange rate changes affect the aggregate trade balance.

Our paper belongs to the recent and growing literature on how heterogeneous firms respond to exchange rate changes (e.g. Baggs, Beaulieu, and Fung, 2009; Berman, Martin, and Mayer, 2012; Amiti, Itskhoki, and Konings, 2014; Cheung and Sengupta, 2013; Freund, Chang, and Wei, 2011; Tang and Zhang, 2012; Liu, Lu, and Zhou, 2013; Li, Ma, and Xu, 2015). Most papers in this literature have focused on one specific response of heterogeneous firms to exchange rate changes. ${ }^{6}$ Our focus, however, is broader and pertains to a very different research question, namely how the CNY revaluation affects the China-US trade balance, and to do so we consider the role of processing trade and firm dynamics in a unified empirical framework. In addition, we are to the best of our knowledge the first paper to extend the firm-level Chinese Customs data set to 2011 and to use this data to empirically explore the impact of the large CNY appreciation on the China-US trade balance.

Our paper is also related to the literature that emphasizes the importance of outsourcing and processing trade in the Chinese trade. ${ }^{7,8}$ While our paper follows this literature in regards to how to define processing firms, our focus is different in that we study how processing firms are different from ordinary firms in terms of their response to exchange rate changes and the resulting trade balance changes.

Our results show that the response of Chinese firms to exchanges rate changes (in terms of either export or import values or in terms of the likelihood of export or import market entry and exit) strongly depends on firm involvement, and degree of involvement, in processing trade. For ordinary firms with no

\footnotetext{
${ }^{6}$ For example, Berman, Martin and Mayer (2012), Amiti, Itskhoki, and Konings (2014), and Li, Ma, and Xu (2015) focus on the exchange rate pass-through to the prices of exporting firms.

${ }^{7}$ Following Feenstra and Hanson (2005), we define firms involved in processing trade as firms involved in international outsourcing thus interpreting a high degree of processing trade is indicative of a high degree of international outsourcing.

${ }^{8}$ See, for example, Yu (2015) who explores the role of processing trade in Chinese firm productivity and finds that the positive impact of a reduction in input tariffs on firm productivity is decreasing as firm processing import share grows.
} 
processing trade involvement, we find large export and import elasticities to exchange rate changes. Specifically, we find that a 10\% appreciation of the CNY vis-à-vis the USD is associated with a roughly $30 \%$ decrease in Chinese exports to US and a roughly 15\% increase in Chinese imports from the US. For mixed firms with some transactions in processing trade, the estimated export and import elasticities are significantly smaller (approximately $13 \%$ for exports and $9 \%$ for imports). Interestingly, for pure processing firms, the negative impact of $\mathrm{CNY}$ appreciation on exports and the positive impact on imports are not statistically significant. Consistent with these findings, we obtain similar results when estimating the impact of exchange rate changes on firm export and import market entry and exit. Perhaps most importantly, the results of our firm-level estimation of trade elasticities show that, overall, the trade balance between China and the US responds strongly to changes in the CNY/USD rate. We find that this is especially true when we distinguish between ordinary and processing firms and, furthermore, that the strong firm-level response to exchange rate changes is driven by continuing firms adjusting their intensive margins. Overall, these results thus suggest that the influence of exchange rates on trade flows is stronger than previously thought and add to the policy debate on beggar-thy-neighbor policies and currency wars by, at least in principle, validating the underlying premise of such policies. ${ }^{9}$

The remainder of the paper is organized as follows. Section 2 provides a brief overview of the evolution of the Chinese exchange rate regime and the China-US trade imbalance in goods. Section 3 describes the data and key variables. Section 4 presents our empirical analysis and results. Section 5 discusses a counterfactual analysis of the magnitude of trade balance effects of exchange rate changes. Section 6 summarizes a number of robustness checks. Section 7 concludes the paper.

\section{The Evolution of the Chinese Exchange Rate Regime and the China-US Trade Imbalance}

During our 2000 to 2011 sample period, the Chinese exchange rate regime rotated between fixed and managed float regimes. From 1994 to July 2005, China maintained a fixed exchange rate regime with the

\footnotetext{
${ }^{9}$ It is beyond the scope of our analysis to consider possible foreign country policy responses to an initial domestic policy induced depreciation and our findings do not in any way endorse or encourage beggar-thy-neighbor policies and currency wars.
} 
Chinese currency pegged at CNY/USD 8.28 for most of the time. China revalued the CNY on July 21, 2005, to CNY/USD 8.11, and changed the exchange rate regime from fixed against the USD to a managed float against a reference basket of currencies. Under this regime, the CNY is highly managed but allowed to fluctuate within a narrow band. The band of fluctuation was widened slightly in 2007 . China reverted to a fixed exchange rate regime with the CNY pegged to the USD at the rate of CNY/USD 6.83 in July 2008. This regime ended in June 2010 when China returned to a managed float. ${ }^{10}$

Figure 1 displays the evolution of the CNY/USD rate over the sample period and shows that, following the exchange rate reform in 2005, the CNY has appreciated by 22 percent vis-à-vis the USD from the beginning of 2005 to the end of 2011. This large appreciation of the CNY provides us with the variation needed in order to investigate the China-US trade balance response to currency fluctuations.

The US have been running a persistent and increasing trade deficit against China since 1985. In 2011, the US-China trade deficit in goods reached roughly USD 200 billion according to the Chinese National Bureau of Statistics (or roughly USD 300 billion according to the US Bureau of Economic Analysis). ${ }^{11}$

Figure 2 shows the bilateral exports, imports, and trade balance of goods between China and the US over the 2000-2011 period according to data from the Chinese National Bureau of Statistics. The figure shows that from 2000 to 2011 the US trade deficit with China increased continuously with the exception of the 2008-2009 global financial crisis peak period. Specifically, the imbalance in goods trading between China and the US increased from USD 30 billion in 2000 to USD 200 billion in $2011 .{ }^{12}$

As noted previously, most of the earlier trade literature largely relied on aggregate trade data to analyze the impact of exchange rate changes on the trade imbalance between China and the US and,

\footnotetext{
${ }^{10}$ See, for example, Liu, Lu, and Zhou (2013) for additional details.

${ }^{11}$ The trade balance in goods is an important measure of the US external economy. The bilateral trade imbalance in goods between China and US contributes to more than $90 \%$ of the US current account deficit towards China in 2011. It also accounts for about $40 \%$ of overall US trade deficit in goods in 2011 according to international transactions data from the Bureau of Economic Analysis.

${ }^{12}$ The China-US trade imbalance based on US official statistics has shown a similar pattern as that based on Chinese official statistics. However, the magnitude of the trade imbalance is bigger according to official US statistics compared to official Chinese statistics, increasing from USD 83 billion in 2000 to USD 300 billion in 2011 according to US data. This discrepancy might stem from US trade data including entrepot trade via Hong Kong (e.g. Koopman, Wang, and Wei, 2012). These differences are discussed in detail in Schindler and Beckett (2005).
} 
typically, did not find strong evidence that appreciation of the CNY is associated with a shrinking the trade imbalance. This is seemingly consistent with the evolution of the exchange rate and aggregated trade imbalance trends shown in Figures 1 and 2. The two figures show that Chinese exports and imports keep increasing alongside the CNY appreciation and, more importantly, exports from China to the US increase by a greater amount than Chinese imports from the US, causing the trade imbalance between China and the US to expand despite the CNY appreciation. However, since aggregate data can hide heterogeneous firm responses to exchange rate changes the evolution of aggregate data does not constitute conclusive evidence regarding the influence of the exchange rate on the trade balance. It is also for this reason that we in this paper employ transactions level trade data to decompose how heterogeneous firms respond to exchange rate movements and, in turn, aggregate the firm level responses to shed better light on how the China-US trade imbalance responds to exchange rate changes.

\section{Data Description and Key Variables}

\subsection{Chinese Customs Data 2000-2011}

Our analysis is facilitated by access to transactions-level Chinese Customs data from 2000 to 2011, obtained from China's General Administration of Customs. This extremely disaggregated trade data is unique in terms of representativeness and comprehensiveness.

First of all, the data covers the universe of all Chinese import and export transactions between 2000 and 2011. By aggregating across all transactions covered by the Chinese Customs data we can obtain virtually the exact amount of the official Chinese trade balance. This allows for a counterfactual analysis in which we make use of our firm-level based empirical analysis and estimates to make predictions regarding trade balance changes caused by exchange rate changes. ${ }^{13}$

Second, the Chinese Customs data provides values (in USD) and quantity of exports and imports at the HS 8-digit level (with more than 7000 product categories) from a firm to counterpart country. More

\footnotetext{
${ }^{13}$ As mentioned earlier, we have updated the data to 2011 in order to explore the impact of the large currency appreciation after the 2005 exchange rate reform. The same data set but ending in 2005 has been used in previous contributions (e.g. Manova and Zhang, 2009 and 2012, and Ahn, Khandelwal, and Wei, 2011).
} 
importantly, this rich data set also contains information regarding the customs regime pertaining to each transaction (e.g. processing versus ordinary trade). This provides us with the finest unit of observation possible for distinguishing between firms involved in international trade in different modes, thereby adding an unusual level of depth to the analysis of how different firms respond to exchange rate changes.

The Chinese Customs data is available at the monthly frequency from 2000 to 2006 and at the yearly frequency from 2007 to 2011 . To construct a consistent sample we aggregate the monthly data to yearly data for the years 2000-2006. We naturally consider only export and import transactions between China and the US since studying the impact of exchange rate changes on the China-US trade balance is the focus of our research. ${ }^{14}$

\subsection{Ordinary and Processing Trade Firms in China-US Trade}

A key innovation of this paper is to study how firm-level exports and imports respond to exchange rate changes depending on the degree of firm involvement in processing trade. ${ }^{15}$ The Chinese General Administration of Customs classifies 16 different types of Chinese processing trade. ${ }^{16}$ Among all types of processing trade, "processing with assembly" and "processing with inputs" are by far the two most important modes of Chinese processing trade, accounting for more than $90 \%$ of all processing trade. In this paper, we focus on these two modes of processing trade and refer to them collectively as "processing trade".

For processing with assembly, a domestic Chinese firm obtains raw materials and parts from its foreign trading partner without any payment. After local processing, the firm must sell its product to the

\footnotetext{
${ }^{14}$ Table 1 provides a brief summary of the distribution of China-US trade during 2000-2011. The table shows that total exports from China to the US increased by $17 \%$ annually, from USD 52 billion in 2000 to USD 324 billion in 2011. Total imports increased by 15\% annually, from USD 22 billion in 2000 to USD 122 billion in 2011. Table 1 also shows the increasing participation of Chinese firms in the China-US trade: the total number of Chinese exporting (importing) firms increased from less than 24,000 (20,500) in 2000 to over 99,000 $(44,000)$ in 2011.

${ }^{15}$ As an important part of trade liberalization, the Chinese government has since the early 1980s encouraged Chinese firms to import all or part of their raw materials and intermediate inputs, and re-export final value-added goods after local processing or assembly.

${ }^{16}$ The 16 types of processing trade include foreign aid, compensation trade, processing with assembly, processing with inputs, goods on consignment, goods on lease, border trade, contracting projects, outward processing, barter trade, customs warehouse trade, and entrepot trade by bonded area.
} 
same foreign trading partner and charges an assembly fee to do so. For processing with inputs, a domestic Chinese firm pays for raw materials to its foreign seller. The firm can then sell its final good to other foreign countries after local processing (Yu, 2015). These two types of processing trade are thus different in terms of the underlying contractual terms vis-à-vis the foreign firms. However, they share one common characteristic that is crucial for our research, namely that Chinese firms involved in processing trade must use imported intermediate inputs in order to produce the final good for exporting. This characteristic will likely affect how processing firms respond to exchange rate changes as exchange rate changes will simultaneously affect the value of their imported intermediate inputs as well as the value of their exported final goods.

In our baseline analysis, we use the following two definitions for defining firm engagement in processing trade. First, we follow Yu (2015) and define a firm as an ordinary exporter if none of the export transactions of a given firm is coded as processing trade. Second, to account for different degrees of involvement in processing trade, we then define a firm as a pure processing exporter if all of the export transactions of a given firm are coded as processing trade, and we define a firm as a mixed exporter if a firm engages in both processing transactions and ordinary transactions. Similarly, we define a firm as an ordinary importer if a firm has no processing transactions, as a pure processing importer if all the import transactions of the given firm are coded as processing trade, and otherwise we define a firm as a mixed importer.

Table 2 shows the distribution of the above-defined three types of Chinese exporters and importers between 2000 and 2011. Ordinary exporters and importers account for the majority of the exporters and importers (69\% and $48 \%$ on average, respectively). However, the export and import values generated by these firms are $22 \%$ each. As for pure processing exporters and importers, the share of the number of firms and the export and import values they generate kept decreasing over the sample period under study. On average, these firms account for $16 \%$ of the total number of exporters and $37 \%$ of the total number of importers, respectively, and together they generate $33 \%$ of total exports and $15 \%$ of total imports between China and US. Compared to pure processing trade firms, the average shares of the 
number of mixed exporters and importers are smaller (15\% of total number of exporters and $15 \%$ of total number of importers, respectively). However, the mixed exporters and importers generate a larger share of export and import values than those of pure processing trade firms (45\% of total value of exports and $63 \%$ of total value of imports, respectively).

Similar to Yu (2015), we also use in our empirical analysis the share of processing trade of total firm trade as a continuous measure of the extent of processing trade engagement of a given firm.

\section{3. $\quad$ Firm Dynamics in China-US Trade}

Another key innovation of this paper is that we examine how the firm-level dynamics affect the changes in the aggregate China-US trade balance. To do so, we follow Bernard, Jensen, Redding, and Schott (2009) and Tang and Zhang (2012) in decomposing the yearly changes in exports and imports between China and the US into changes due to continuing firms (C), entry firms (N), and exit firms (E) as follows:

$$
\Delta x_{t}=\sum_{f \in C} \Delta x_{f t}+\sum_{f \in N} x_{f t}-\sum_{f \in E} x_{f t-1}
$$

where $\Delta x_{t}$ is the aggregate change in exports or imports between year $t$ and $t-1$. This aggregate change of trade is composed of two terms. $\sum_{f \in C} \Delta x_{f t}$ is the sum of change of continuing firm f's exports or imports between years $t$ and $t-1$ (the changes on the intensive margin of trade), and $\sum_{f \in N} x_{f t}$ and $\sum_{f \in E} x_{f t-1}$ are the sums of entering firm $f$ 's exports or imports at year $t$ and the sum of exiting firm $f$ 's exports or imports at year $t-1$ (the changes on the extensive margin of trade), respectively.

Using our unique firm-level trade data, we thus decompose the yearly changes in aggregate exports and imports between China and the US into the firm dynamics described in Table 3. We define continuing exporters as firms that export in year $t-1$ and continue to export in year $t$, entry exporters as any exporters that did not export in year $t-1$, but started exporting in year $t$, and exit exporters as those that export in year $t-1$ but did not export in year $t$. Similarly, we classify different types of importers based on their import status in years $t$ and $t-1$. As previously shown in Table 1 , the number of exporters and importers between China and the US increased sharply during the 2000-2011 period. Behind this net 
increase there were significant turnovers of firms. Importantly, these firms contribute greatly to the aggregate yearly changes in trade between China and the US. As Table 3 shows, the average annual change in exports between China and the US is USD 25 billion, to which continuing firms contribute roughly $91 \%$ of the increase, entry firms contribute roughly $38 \%$ of the increase, and exit firms contribute roughly $-28 \%$ of the increase. Similarly, continuing firms contribute $90 \%$ of the average annual increase in imports of about USD 9 billion, entry firms contribute $20 \%$, and exit firms contribute $-10 \%$ of the increase. ${ }^{17}$

These preliminary findings suggest that firm dynamics should play an important role for our understanding of the trade imbalance between China and the US.

\section{Empirical Analysis}

\subsection{The Impact of Exchange Rate Movement on Changes of Firm Exports and Imports}

We first examine the impact of exchange rate changes on firm export and import values when explicitly considering firm involvement in processing trade. In contrast to the traditional approach of using aggregate trade data and time-series analysis (e.g. Cheung, Chinn, and Qian, 2012, and Thorbecke, 2006), we follow the more recent literature in using disaggregate firm-level trade data and panel-data estimations (e.g. Amiti, Itskhoki, and Konnings, 2014, and Tang and Zhang, 2012). Specifically, we estimate the following regressions:

$$
\begin{aligned}
& \Delta \ln \left(\text { Exports }_{f i t}\right)=\alpha \Delta \ln \left(N E R_{t}\right)+\beta \Delta \ln \left(W E R_{t}\right)+\gamma \Delta \ln \left(G D P_{t}^{U S A}\right)+t+t^{2}+\delta_{f}+\delta_{i}+\varepsilon_{f i t} \\
& \Delta \ln \left(\text { Imports }_{f i t}\right)=\alpha \Delta \ln \left(N E R_{t}\right)+\beta \Delta \ln \left(W E R_{t}\right)+\gamma \Delta \ln \left(G D P_{t}^{C H N}\right)+t+t^{2}+\delta_{f}+\delta_{i}+\varepsilon_{f i t}
\end{aligned}
$$

where $f, i$, and $t$ represent firm, industry and year, respectively. $\Delta \ln \left(\right.$ Exports $\left._{f i t}\right)$ denotes the percentage change in Chinese firm f's exports to the US and $\Delta \ln \left(\right.$ Imports $\left._{f i t}\right)$ denotes the percentage change in

\footnotetext{
${ }^{17}$ These decomposition findings are similar to those of Bernard, Jensen, Redding, and Schott (2009) but different from those of Tang and Zhang (2012). The former decomposes the yearly changes of US total exports and find that annual changes in US exports are almost exclusively driven by changes in the intensive margin (changes of exports by continuing exporters). However, the latter decomposes total Chinese exports and find that the intensive margin only accounts for about half of total export growth between 2000 and 2006.
} 
Chinese firm $f$ 's imports from the US from year $t-1$ to $t . \Delta \ln \left(N E R_{t}\right)$ is the percentage annual change in the nominal CNY/USD exchange rate ${ }^{18}$. The sign and magnitude of the estimated parameter $\alpha$ is of main interest. Since the exchange rate is measured in CNY per USD terms, we expect $\alpha$ to be positive in our export regressions and negative in our import regressions (consistent with the notion that a depreciation of the CNY relative to the USD will, on average, lead to an increase in export values and a decrease in import values).

In all our regressions, to take into account the substitutability between Chinese goods and goods from other countries, we control for the weighted exchange rate of the CNY relative to other Chinese trading partners. ${ }^{19}$ We also use the percentage changes of US GDP and Chinese GDP to control for the impact of demand on firm exports and imports. Furthermore, we use time trend and square time trend to control for the aggregate trend in firm exports and imports, and we control for unobserved demand and supply changes at the industry level by including industry fixed effects. Finally, since our context is panel data at the firm-level, we are able to use firm fixed effects to control for any unobserved firm-specific characteristics that affect firm-level export or import changes. Our standard errors are clustered at the firm level.

Importantly, we extend our baseline regressions to consider the importance of processing trade involvement for the firm response to exchange rate changes. To do so, as discussed in Section 3, we classify firms into different groups depending on their degree of involvement in processing trade. In our baseline regressions we distinguish between ordinary, mixed, and pure processing firms and estimate Equations (2) and (3) for the three different groups of firms separately. Doing so allows us to answer our research question regarding whether different degrees of processing trade involvement is systematically related to the firm response to exchange rate changes.

\footnotetext{
${ }^{18}$ As Tang and Zhang (2012) point out, most of the adjustments of Chinese firms in response to exchange rate changes take place in the first six months of the exchange rate change. Therefore, in our baseline analysis, we use the contemporary annual exchange rate change. In our robustness section we consider 1-year and 2-year lagged exchange rate changes.

${ }^{19}$ This weighted exchange rate index is calculated using time-varying trade weights across the top 30 trading partners of China (excluding USA) in each year and bilateral exchange rates between the CNY and the respective trading partner currencies. See Thorbecke (2006).
} 
We also extend our analysis by interacting the continuous variable, the share of processing transactions, with the change in the exchange rate in order to provide an additional layer of evidence in regards to how firms react to exchange rate changes given their degree of processing trade involvement. To do so we propose the following regression model:

$$
\begin{aligned}
\Delta \ln \left(\text { Exports }_{f i t}\right)= & \alpha \Delta \ln \left(N E R_{t}\right)+\varphi \Delta \ln \left(N E R_{t}\right) \times \text { ProcessingTrade }_{f t} \\
& +\beta \Delta \ln \left(W E R_{t}\right)+\gamma \Delta \ln \left(G D P_{t}^{U S A}\right)+t+t^{2}+\delta_{f}+\delta_{i}+\varepsilon_{f i t} \\
\Delta \ln \left(\text { Imports }_{f i t}\right)= & \alpha \Delta \ln \left(N E R_{t}\right)+\varphi \Delta \ln \left(N E R_{t}\right) \times \text { ProcessingTrade }_{f t} \\
& +\beta \Delta \ln \left(W E R_{t}\right)+\gamma \Delta \ln \left(G D P_{t}^{C H N}\right)+t+t^{2}+\delta_{f}+\delta_{i}+\varepsilon_{f i t}
\end{aligned}
$$

where ProcessingTrade $f t$ denotes the share of processing export/import transactions for firm $f$ in year $t$. An increasing share of processing exports indicates that firms need more imported inputs in order to export. When the CNY depreciates, the higher cost of imported inputs may increase the marginal cost of production and hence dampen the positive effects of the CNY depreciation on the export value (and vice versa for CNY appreciations) Accordingly, we expect the coefficient estimate $\varphi$ to be negative in our export regressions and positive in our import regressions.

Panel A of Table 4 presents the baseline regression results regarding the influence of exchange rate changes on firm exports. As Column (1) shows (Equation 2 without considering processing trade), our estimate of the overall export elasticity is 1.351 , implying that a $10 \%$ depreciation (appreciation) of the CNY is associated with a $13.51 \%$ increase (decrease) in exports from China to US. Columns (2) to (4) show the results of our analysis when we incorporate our classification of firms as being either ordinary, mixed, or pure processing firms (Equation 2 with considering processing trade). The results are striking. For ordinary exporters the estimated export elasticity is 3.09 and statistically significant. The estimated export elasticity for mixed processing firm is also positive and statistically significant but smaller, at about 1.30, suggesting that partial involvement in processing trade dampens the positive (negative) effects of CNY depreciation (appreciation) on exports. For pure processing firms, however, the positive (negative) effect of CNY depreciation (appreciation) on exports is no longer statistically significant, implying that for processing firms there is no discernible exchange rate effect on exports. The reported 
Chi-square test statistics show that the export elasticities across ordinary, mixed, and pure processing firms are statistically different.

Column (5) reports the estimates of the interaction effects of exchange rate and share of processing transactions on firm exports (Equation 4). As expected, we find that the estimated coefficient on the interaction term is negative, and statistically significant, indicating that as the share of processing transactions increases, the positive (negative) effects of CNY depreciation (appreciation) on firm exports gets smaller.

Panel $\mathrm{B}$ of Table 4 presents the regression results pertaining to the impact of exchange rate changes on firm imports. Column (1) shows that our estimate of the overall import elasticity is 1.617 , indicating that a $10 \%$ appreciation (depreciation) of the CNY is associated with a $16.17 \%$ increase (decrease) in imports from China to US (Equation 3 without considering processing trade). Columns (2) to (4) display the baseline regression results for ordinary, mixed, and pure processing firms (Equations 3 with considering processing trade). Once again the results are striking. The estimated import elasticity for ordinary importers is 1.47 and statistically significant. Partial involvement in processing trade dampens the positive (negative) effects of CNY appreciation (depreciation) on imports, i.e. the estimated impact is still significantly positive but much smaller for mixed processing firm, at 0.87 . For pure processing firms, however, the positive (negative) effect of appreciation (depreciation) is, as in the case of exporters, insignificant.

Column (5) reports the results of our estimation of the interaction effects of exchange rate and share of processing transactions on firm imports (Equation 5). Mirroring our findings for exporting firms, our results show that the estimated interaction term is significantly positive, indicating that as the share of processing transactions increases, the positive (negative) effects of appreciation (depreciation) on firm imports gets smaller. ${ }^{20}$

\footnotetext{
${ }^{20}$ We find that the estimated coefficients of the trade-weighted exchange rate of the CNY relative to the currencies of other countries are always statistically insignificant. Furthermore, we find that the income elasticity of Chinese exports to the US is significant. The estimates of the income elasticity of Chinese imports from the US, however, are
} 


\subsection{The Impact of Exchange Rate Changes on Firm Entry and Exit}

We now turn to the analysis of the influence of exchange rate changes on firm entry and exit in China-US export and import markets and, once again, we consider whether firm responses differ across different degrees of processing trade involvement. Our starting point is the following regression models:

$$
\begin{gathered}
\operatorname{Prob}_{\left(\text {Entry }_{\text {fit }}=1\right)}=\Phi\left(\alpha \Delta \ln \left(N E R_{t}\right)+\beta \Delta \ln \left(W E R_{t}\right)+\gamma \Delta \ln \left(G D P_{t}\right)+t+t^{2}+\delta_{i}\right) \\
\quad \operatorname{Prob}\left(\text { Exit }_{\text {fit }}=1\right)=\Phi\left(\alpha \Delta \ln \left(N E R_{t}\right)+\beta \Delta \ln \left(W E R_{t}\right)+\gamma \Delta \ln \left(G D P_{t}\right)+t+t^{2}+\delta_{i}\right)
\end{gathered}
$$

where $f, i$, and $t$ represent firm, industry and year, respectively; Entry $y_{f i t}$ is the probability of export or import market entry and equals 1 if firm $f$ does not export to the US or import from the US in year $t-1$, but starts exporting to the US or starts importing from the US in year $t$; Entry $y_{\text {fit }}$ equals 0 if firm $f$ keeps exporting to the US or keeps importing from the US during year $t-1$ and $t$; Exit fit $_{\text {it }}$ is the probability of export or import marke exit and equals 1 if firm $f$ exports to the US or imports from the US in year $t$ - 1 ,

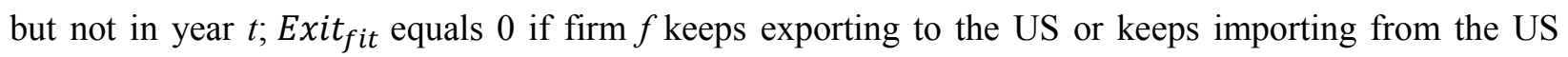
during year $t-1$ and $t .^{21}$ Consistent with our discussion of the focal parameter estimate $\alpha$ in the context of our earlier regression models, we expect $\alpha$ to be positive in our firm export entry regressions and negative in our firm export exit regressions and, similarly, we expect $\alpha$ to be negative in our firm import entry regressions and positive in our firm import exit regressions. ${ }^{22}$

In the same fashion as before we also extend our entry/exit analysis to take into account firm involvement in processing trade using our distinction between ordinary firms, mixed processing firms and pure processing firm. To do so we estimate Equations (6) and (7) separately across each of the three types of firms and, in turn, compare the firm type specific parameter estimates of $\alpha$.

not statistically significant. These findings are generally consistent Cheung, Chinn, and Qian (2012), Thorbeck (2006) and others.

${ }^{21}$ The empirical setup described by Equations (6) and (7) follows Tang and Zhang (2012), and Li, Ma, and Xu (2015).

${ }^{22}$ As in the previous estimations, we control for the weighted CNY exchange rate, the impact of demand on firm entry and exit, the aggregate trend in firm exit and entry, as well as industry fixed effects. We cluster the standard errors at the industry level to adjust for within-industry correlation of residuals. 
Finally, also as before, we interact the share of processing transactions with the exchange rate variable and, to do so, estimate the following regression models:

$$
\begin{aligned}
& \operatorname{Prob}\left(\text { Entry }_{\text {fit }}=1\right)=\Phi\left(\alpha \Delta \ln \left(N E R_{t}\right)+\varphi \Delta \ln \left(N E R_{t}\right) \times \text { ProcessingTrade }_{f t}\right. \\
& \left.+\beta \Delta \ln \left(W E R_{t}\right)+\gamma \Delta \ln \left(G D P_{t}\right)+t+t^{2}+\delta_{i}\right) \\
& \operatorname{Prob}\left(\text { Exit }_{f i t}=1\right)=\Phi\left(\alpha \Delta \ln \left(N E R_{t}\right)+\varphi \Delta \ln \left(N E R_{t}\right) \times \text { ProcessingTrade }_{f t-1}\right. \\
& \left.+\beta \Delta \ln \left(W E R_{t}\right)+\gamma \Delta \ln \left(G D P_{t}\right)+t+t^{2}+\delta_{i}\right)
\end{aligned}
$$

where all variables are as previously defined. Since a depreciation (appreciation) of the CNY is associated with higher (lower) cost of imported inputs and thus an increase (decrease) in the marginal cost of production, an increasing (decreasing) share of processing exports is likely to partially offset the positive (negative) effects of CNY depreciation (appreciation) on export entry. Accordingly, we would expect the coefficient estimate $\varphi$ to be negative in our export entry regressions and positive in our import entry regressions, and vice versa with respect to export and import exit.

Table 5 presents the results pertaining to Equations (6) and (8). We report the marginal effects of probit regressions in order to facilitate a comparison of magnitudes. Panel A reports the estimated probability of a Chinese firm entering into the export market. Column (1) of Panel A shows that there is a statistically significant and positive relation between CNY changes and the probability of firm entry into exporting. Importantly, this relationship between exchange rate change and probability of export market entry differs significantly across firms with different degrees of processing trade involvement. As Columns (2) to (4) show, ordinary exporting firms are more likely to enter into exporting to the US in response to a $\mathrm{CNY}$ depreciation compared to mixed processing and pure processing firms. The results reported in Column (5) offer further evidence that the likelihood of export market entry in response to currency fluctuations depends on the intensity of processing trade in overall firm exports.

Panel B of Table 5 reports the estimation results of the probability of entering into importing from the US. Consistent with our priors, we find statistically significant and negative relationship between changes in the CNY/USD rate and the probability of import market entry into. Again, as Columns (2) to (5) show, this relationship differs markedly across the different degrees of processing trade involvement. 
Turning to the estimation results pertaining to Equations (7) and (9), Panel A of Table 6 shows the estimated probability of export market exit and Panel B of Table 6 shows the estimated probability of import market exit. Column (1) of Panel A shows that, overall, a depreciation (appreciation) of the CNY decreases (increases) the probability of firm export market exit. The positive effect of CNY depreciation on firm survival in the export market is stronger for ordinary and mixed processing firms (Columns 2 and 3) but statistically insignificant for pure processing firms (Column 4). Interestingly, the magnitude of the positive effect on survival is decreasing as the share of processing trade is increasing (Column 5). The import market exit results reported in Panel B virtually mirror the export market exit results.

\section{Counterfactual Analysis of Economic Effects}

We now use our firm-level estimates to facilitate a counterfactual "back-of-the-envelope" calculation in an attempt to quantify the China-US trade balance effect of a 10 percent appreciation of the CNY against the USD. Our starting point is to rewrite our Equation (1) decomposition of total exports and imports changes as follows:

$$
\begin{aligned}
& \Delta \text { Exports }_{t}=\Delta \operatorname{Exports}_{t}^{C}+N_{t}^{N} \overline{\operatorname{Exports}}_{t}^{N}-N_{t-1}^{E} \overline{\operatorname{Exports}}_{t-1}^{E} \\
& \text { Imports }_{t}=\Delta \text { Imports }_{t}^{C}+N_{t}^{N} \overline{\operatorname{Imports}}_{t}^{N}-N_{t-1}^{E} \overline{\operatorname{Import}}_{t-1}^{E}
\end{aligned}
$$

Employing our regression models and coefficient estimates of the previous section, a 10 percent appreciation of the CNY will change exports and imports as follows:

$$
\begin{aligned}
\Delta \text { Exports }_{t} & =\left(\alpha_{\text {Ex }}^{C} \text { Exports }_{t}^{C}+\alpha_{E x}^{N} N_{t}^{N} \overline{\text { Exports }}_{t}^{N}-\alpha_{E x}^{E} N_{t-1}^{E} \overline{\text { Exports }}_{t-1}^{E}\right) \times(-10 \%) \\
\Delta \text { Imports }_{t} & =\left(\alpha_{\text {Im }}^{C} \text { Imports }_{t}^{C}+\alpha_{I m}^{N} N_{t}^{N} \overline{\operatorname{Imports}}_{t}^{N}-\alpha_{I m}^{E} N_{t-1}^{E} \overline{\operatorname{Imports}}_{t-1}^{E}\right) \times(-10 \%)
\end{aligned}
$$

We initially treat all firms as homogeneous and apply the coefficient estimate for $\alpha_{E x}^{C}$ from Column (1) of Table 4, the coefficient estimate for $\alpha_{E x}^{N}$ from Column (1) of Table 5, and the coefficient estimate for $\alpha_{E x}^{E}$ from Column (1) of Table 6, i.e. the respective coefficient estimates obtained in estimations that do not consider different degrees of processing trade involvement. Combined with the relevant 2011 Customs data statistics, we then calculate the consequential changes in exports and imports 
to, in turn, evaluate the aggregate effect on the China-US trade balance. The results, reported in Panel A of Table 7, suggest that the 2011 trade imbalance between China and the US would have been reduced by USD 24 billion had the CNY appreciated by $10 \%$ against the USD.

When we distinguish between ordinary, mixed, and pure processing firms we make use of the coefficient estimates from Columns (2) to (4) in Table 4 for $\alpha_{E x}^{C}$, the coefficient estimates from Columns (2) to (4) in Table 5 for $\alpha_{E x}^{N}$, and the coefficient estimates from Columns (2) to (4) in Table 6 for $\alpha_{E x}^{E}$. The counterfactual calculation results are reported in Panel B of Table 7. They suggest that the 2011 trade imbalance between China and the US would have been USD 70 billion less had the CNY appreciated by $10 \%{ }^{23}$

Although by construction imprecise and merely indicative, these counterfactual findings are particularly illuminating as they not only suggest that the economic effects of exchange rate changes in regards to the trade balance are very substantial, they also highlight the importance of explicitly considering firm level heterogeneity in the trade sector exchange rate response in order to avoid underestimating the economic importance of exchange rate changes.

\section{Robustness Checks}

In this section, we check the robustness of our main results by considering the firm level trade effects of real rather than nominal exchange rates, by employing alternative processing trade firm definitions, by assessing the effects of lagged exchange rates, and by analyzing separately the post-exchange rate reform period.

First, we re-estimate all models using two different real exchange rates series instead of the nominal exchange rate employed in our baseline estimations. Our first real exchange rate measure is calculated in the traditional fashion by adjusting the nominal rate for Chinese and US Consumer Price Index (CPI) while our second real exchange rate measure is a non-traditional real exchange rate

\footnotetext{
${ }^{23}$ The results shown in Panel $\mathrm{B}$ indicate that most of the hypothetical trade imbalance reduction stems from exchange rate induced changes in the exports and imports of continuing firms (decreased exports from China to the US by USD 85 billion and increased imports by China from the US by USD 15 billion).
} 
calculated by adjusting the nominal rate for Chinese and US unit labor cost (ULC) to more directly account for the cost difference across countries. ${ }^{24}$ The results of the re-estimations are reported in Table 8.1. As the table shows, regardless of whether we use CPI-adjusted and UCL-adjusted real exchange rates baseline findings remain unchanged.

Second, we re-estimate our models using two alternative firm processing trade definitions. For our first alternative definition we follow $\mathrm{Yu}$ (2015) in defining a firm as a processing exporter (importer) if a firm has at least one export (import) transaction coded as "processing trade" in a given year and define a firm with no export (import) transactions coded as "processing trade" in a given year as an ordinary exporter (importer). Our second alternative definition follows our baseline approach in distinguishing between three categories of firms, only this time a high processing firms is defined as a firm with over $50 \%$ of trade transactions in processing trade, a low processing trade firm is defined as a firm with greater than $0 \%$ but lower than $50 \%$ of trade transactions in processing trade, and finally an ordinary firm is defined as a firm with no processing trade transactions. The results of the re-estimations are provided in Table 8.2. As the results show, when we define each firm as either ordinary or processing, and estimate their export or import exchange rate elasticities separately, we consistently find that the export or import elasticity of ordinary exporters or importers is significantly larger than those of processing exporters or importers (as indicated by the statistically significant $\chi$-square test statistics). Similar findings hold true for the influence of exchange rate changes on the likelihood of China-US export or import market entry and exit. These results are even more pronounced when comparing the results across ordinary and high processing firms.

Third, to assess the influence of lagged exchange rate changes on firm level trade we replace the contemporaneous exchange rate with the 1-year and, in turn, 2-year lagged exchange rate. The results are presented in Table 8.3. As the table shows, the re-estimation results are quite consistent with our

\footnotetext{
${ }^{24}$ ULC is the ratio of average wage over labor productivity, whereas labor productivity is the ratio of real GDP over employment. Chinese and US CPI are obtained from Chinese Statistical Bureau and the US Bureau of Labor Statistics, respectively. Data for calculating Chinese and US ULC are obtained from the China Statistical Yearbook and from the US Bureau of Economic Analysis. Figure 1 shows the evolution of the two real exchange rate series juxtaposed against the nominal rate.
} 
previously discussed baseline findings and, particularly, reaffirm our main conclusion that different types of firms in terms of the degree of processing trade involvement respond differently to exchange rate changes.

Fourth, since the changes in the (nominal) exchange rate during the full 2000 to 2011 period under study mainly occur after the 2005 exchange rate reform, we redo our analysis on the sub-sample of observations belonging to the post-reform period. The post-reform sub-sample results are presented in Table 8.4. Again, the findings are consistent with our full sample baseline results.

\section{Conclusion}

This paper provides an empirical micro-data analysis of the macro effects of exchange rate changes on the aggregate trade balance. Specifically, we use Chinese Customs Data at the firm level to decompose the China-US trade balance into firm-level outcomes and to examine how the exchange rate affects these outcomes. We analyze how different types of firms in terms of processing trade involvement respond to exchange rate changes, and we provide a counterfactual assessment of the effect of a $10 \% \mathrm{CNY}$ appreciation against the USD on the China-US trade balance using our firm-level based coefficient estimates.

Our results suggest that the influence of exchange rates on trade flows is stronger than previously thought and that the premise underlying the policy debate on beggar-thy-neighbor policies and currency wars is, in fact, valid. Moreover, our results indicate that the response of Chinese firms to exchanges rate changes in terms of either export or import values or in terms of the likelihood of export or import market entry or exit strongly depends on the extent to which firms are involved in processing trade. For ordinary firms with no processing trade involvement, we find large export and import exchange rate elasticities. As the degree of processing trade involvement increases, we find that the elasticities become significantly smaller and, for pure processing firms, the negative impact of appreciation on exports and positive impact on imports are statistically in significant. We find similar results when estimating the impact of exchange rate changes on export and import market firm entry and exit. Overall, the results of our firm-level based 
estimation of trade elasticities suggest that the China-US trade balance respond strongly to changes in the CNY-USD rate, especially when we distinguish between different degrees of firm-level processing trade involvement.

In summary, our results offer three key insights. First, they suggest that exchange rate changes have very substantial trade balance effects. This is in and of itself a very important insight in light of the lack of consensus in the trade literature in regards to whether the economic exchange rate effects on the trade balance matter and, particularly, the inability of some of the traditional trade literature to even find a systematic link between exchange rates and trade. It is also a very important insight in regards to policy implications as it, for better or worse, provides strong support for the underlying premise of beggar-thyneighbor policies and currency wars, thereby implying that a policy induced currency depreciation is indeed, at least in principle, a possible path towards export-driven growth. Second, by nature of the origin of our findings, i.e. our use of firm-level trade data, these findings add credence to the notion that firmlevel rather than aggregate trade data is crucial for analyzing the trade effects of exchange rates in order to avoid that off-setting heterogeneous firm level responses that go undetected in aggregate data mask the true effect of exchange rate changes. Third and finally, our results overall suggest that in order to uncover the trade effects of exchange rate changes, at the aggregate as well as at the firm level, it is particularly important to explicitly consider firm heterogeneity in the form of processing trade involvement differences as failure to do so will lead to an underestimation of the economic importance of exchange rate changes in terms of trade balance effects. 


\section{References}

Ahn, J., Khandelwal A., and S.-J. Wei (2011). “The Role of Intermediaries in Facilitating Trade.” Journal of International Economics 84, 73-85.

Amiti, M., Itskhoki, O., and J. Konings (2014). "Importers, Exporters, and Exchange Rate Disconnect." American Economic Review 104, 1942-1978.

Baggs, J., Beaulieu, E., and L. Fung (2009). "Firm Survival, Performance, and the Exchange Rate Shocks." Canadian Journal of Economics 42, 393-421.

Bernard, A., Jensen, B., Redding, S.J., and P.K. Schott (2009). "The Margins of US Trade." American Economic Review Papers and Proceedings 99, 487-493.

Berman, N., Martin, P., and T. Mayer (2012). "How Do Different Exporters React to Exchange Rate Changes? Theory, Empirics and Aggregate Implications." Quarterly Journal of Economics 127, 437-492.

Cheung, Y.-W., Chinn, M.D., and X.W. Qian (2012). “Are Chinese Trade Flows Different?” Journal of International Money and Finance 31, 2127-2146.

Cheung, Y.-W., and R. Sengupta (2013). "Impact of Exchange Rate Movements on Exports: An Analysis of Indian Non-Financial Sector Firms.” Journal of International Money and Finance 39, 231-245.

Dekle, R., Jeong, H., and H. Ryoo (2009). "A Re-Examination of the Exchange Rate Disconnect Puzzle: Evidence from Firm Level Data.” University of Southern California Working Paper.

Feenstra, R., and G.H. Hanson (2005). "Ownership and Control of Outsourcing to China: Estimating the Property-Rights Theory of the Firm.” Quarterly Journal of Economics 120, 729-761.

Fernandes, A., and H. Tang (2012). "Determinants of Vertical Integration in Export Processing.” Journal of Development Economics 99, 396-414.

Freund, C., Chang, H., and S.-J. Wei (2011). "China's Trade Response to Exchange Rate." Working Paper presented at the 68th International Atlantic Economic Conference.

Koopman, R., Wang, Z., and S.-J. Wei (2012). "Estimating Domestic Content in Exports When Processing Trade is Pervasive.” Journal of Development Economics 99, 178-189.

Krugman, P. (2010). "Taking on China." New York Times, 15 March 2010.

Lerner, A. (1944). “The Economics of Control.” New York: Macmillan.

Li, H., Ma, H., and Y. Xu (2015). "How Do Exchange Rate Movements Affect Chinese Exports? - A Firm-Level Investigation.” Journal of International Economics 97, 148-161.

Liu, Q., Lu, Y., and Y. Zhou (2013). "Do Exports Respond to Exchange Rate Changes? Inference from China's Exchange Rate Reform." National University of Singapore Working Paper.

Manova, K., and Z. Zhang (2009). "China's Exporters and Importers: Firms, Products, and Trade Partners.” NBER Working Paper No. 15249. 
Manova, K., and Z. Zhang (2012). "Export Prices across Firms and Destinations.” Quarterly Journal of Economics 127, 379-436.

Marshall, A. (1923). “Money, Credit, and Commerce.” London: Macmillan.

Park, C. (2005). "Coping with Global Imbalances and Asian Currencies." Asian Development Bank Working Paper.

Roubini, N. (2015). “The Dollar Joins the Currency Wars.” Project Syndicate.

Schindler, J.W., and D.H. Beckett (2005). "Adjusting Chinese Bilateral Trade Data: How Big Is China's Trade Surplus?” Federal Reserve International Finance Discussion Paper No. 2005-831.

Tang, H., and Y. Zhang (2012). "Exchange Rates and the Margins of Trade: Evidence from Chinese Exporters.” CESifo Economic Studies 58, 671-702.

Thorbecke, W. (2006). "How Would an Appreciation of the Renminbi Affect the U.S. Trade Deficit with China?" Topics in Macroeconomics 6.

Thorbecke, W., and G. Smith (2010). "How Would an Appreciation of the RMB and Other East Asian Currencies Affect China's Exports?” Review of International Economics 18, 95-108.

Yu, M. (2015). "Processing Trade, Tariff Reductions, and Firm Productivity: Evidence from Chinese Firms.” Economic Journal 125, 943-988. 
Figure 1: The CNY/USD Rate 2000-2011

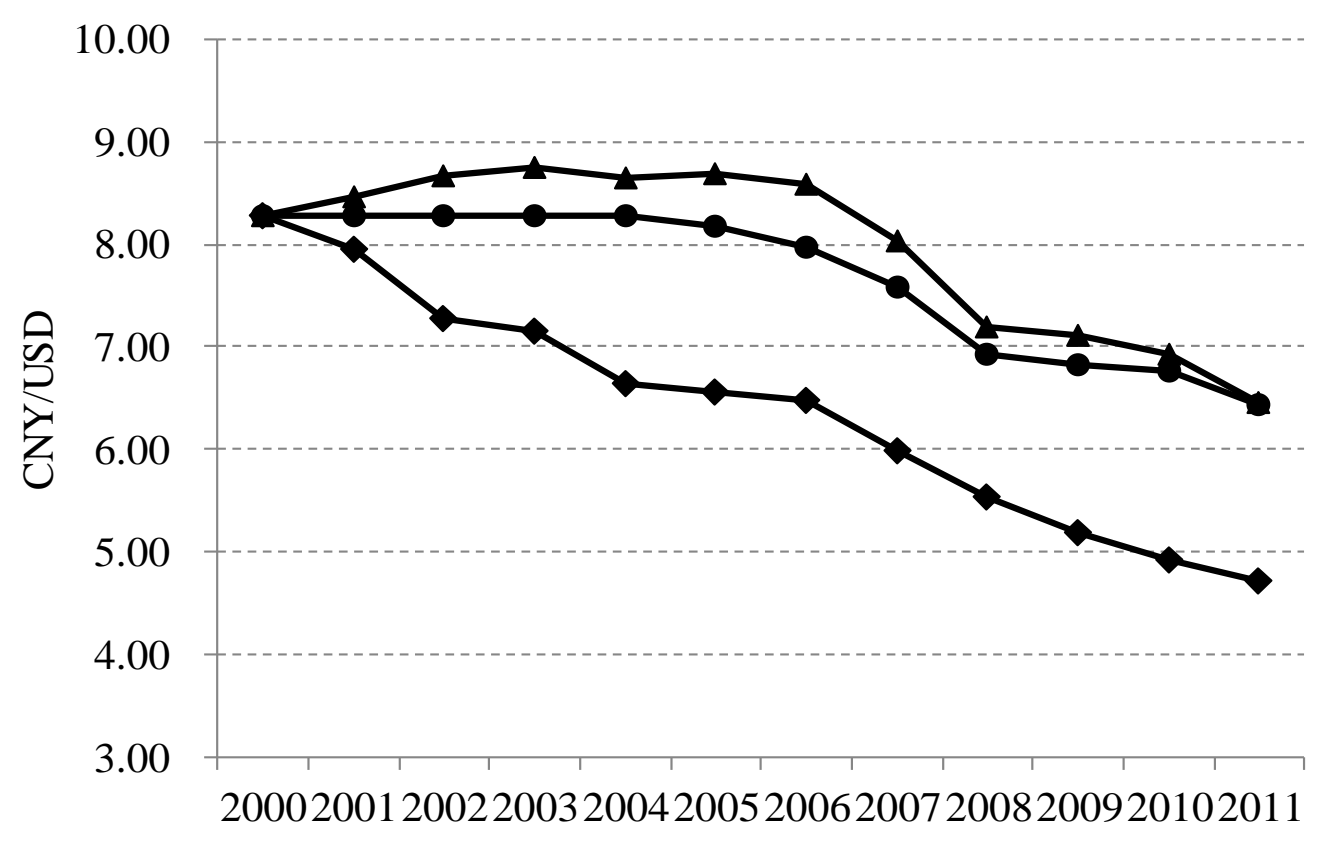

$\rightarrow$ Nominal $\rightarrow$ CPI Adjusted $\rightarrow$ ULC Adjusted 
Figure 2: Goods Trade Balance Between China and US

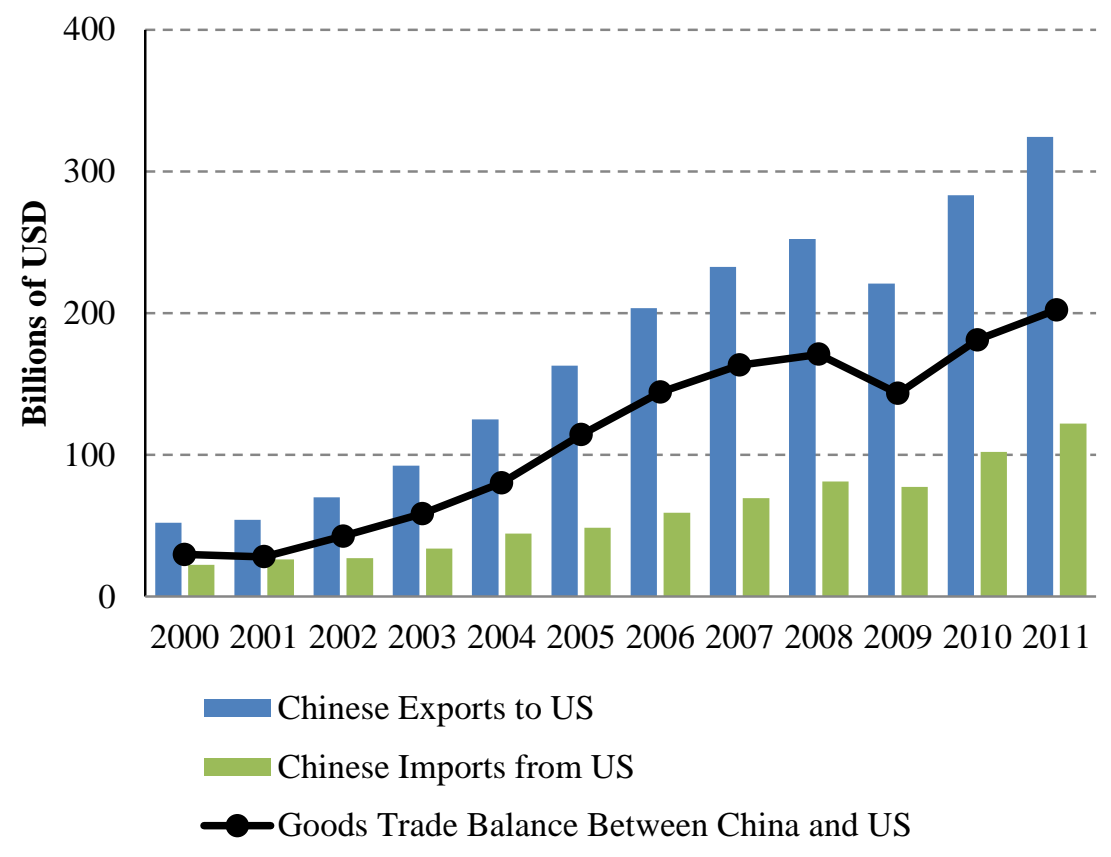

Source: Chinese National Bureau of Statistics 
Table 1: Exports and Imports of Goods Between China and US

\begin{tabular}{cccccc}
\hline \hline & \multicolumn{2}{c}{ Exports } & & \multicolumn{2}{c}{ Imports } \\
\cline { 2 - 3 } \cline { 5 - 6 } Year & $\begin{array}{c}\text { Total Number } \\
\text { of Exporters }\end{array}$ & $\begin{array}{c}\text { Total Exports } \\
\text { (billions of USD) }\end{array}$ & & $\begin{array}{c}\text { Total Number } \\
\text { of Importers }\end{array}$ & $\begin{array}{c}\text { Total Imports } \\
\text { (billions of USD) }\end{array}$ \\
\cline { 5 - 6 } \cline { 5 - 6 } 2000 & 23,438 & 52 & & 20,450 & 22 \\
2001 & 26,172 & 60 & & 21,141 & 29 \\
2002 & 31,835 & 70 & & 24,364 & 27 \\
2003 & 39,555 & 93 & & 28,702 & 34 \\
2004 & 49,878 & 125 & & 33,533 & 45 \\
2005 & 63,193 & 162 & & 36,924 & 48 \\
2006 & 76,081 & 201 & & 39,628 & 58 \\
2007 & 77,845 & 232 & & 36,990 & 69 \\
2008 & 81,575 & 251 & & 39,002 & 81 \\
2009 & 83,681 & 214 & & 38,791 & 77 \\
2010 & 92,305 & 272 & & 42,332 & 102 \\
2011 & 99,681 & 324 & & 44,635 & 122 \\
Avg. Ann. Growth Rate & $13 \%$ & $17 \%$ & & $7 \%$ & $15 \%$ \\
\hline \hline
\end{tabular}

Notes: Authors' calculation based on 2000-2011 Chinese Customs Data. 
Table 2: Distributions of Exporters and Importers by Different Modes of Trade:

Ordinary Trade, Pure Processing Trade, and Mixed Trade

\begin{tabular}{|c|c|c|c|c|c|c|}
\hline \multirow[b]{3}{*}{ Year } & \multicolumn{2}{|c|}{ Ordinary Trade Firms } & \multirow{2}{*}{\multicolumn{2}{|c|}{$\begin{array}{l}\text { Pure Processing Trade Firms } \\
\text { Panel A: Exporters }\end{array}$}} & \multicolumn{2}{|c|}{ Mixed Trade Firms } \\
\hline & \multirow[b]{2}{*}{$\begin{array}{c}\text { Total Number } \\
\text { of Ordinary } \\
\text { Trade Firms }\end{array}$} & \multirow[b]{2}{*}{$\begin{array}{l}\text { Total Exports by } \\
\text { Ordinary Trade Firms } \\
\text { (billions of USD) }\end{array}$} & & & \multirow[b]{2}{*}{$\begin{array}{l}\text { Total Number } \\
\text { of Mixed } \\
\text { Trade Firms }\end{array}$} & \multirow[b]{2}{*}{$\begin{array}{l}\text { Total Exports by } \\
\text { Mixed Trade Firms } \\
\text { (billions of USD) }\end{array}$} \\
\hline & & & $\begin{array}{l}\text { Total Number } \\
\text { of Pure } \\
\text { Processing } \\
\text { Trade Firms }\end{array}$ & $\begin{array}{l}\text { Total Exports by } \\
\text { Pure Processing } \\
\text { Trade Firms } \\
\text { (billions of USD) }\end{array}$ & & \\
\hline 2000 & 12,851 & 7 & 5,778 & 16 & 4,809 & 28.6 \\
\hline 2001 & 14,907 & 8 & 6,137 & 22 & 5,128 & 29.1 \\
\hline 2002 & 19,119 & 11 & 6,841 & 24 & 5,875 & 35.2 \\
\hline 2003 & 25,140 & 15 & 7,792 & 33 & 6,623 & 44.7 \\
\hline 2004 & 33,824 & 21 & 8,492 & 45 & 7,562 & 58.3 \\
\hline 2005 & 44,195 & 30 & 9,789 & 53 & 9,209 & 78.3 \\
\hline 2006 & 56,236 & 42 & 9,824 & 70 & 10,021 & 89.6 \\
\hline 2007 & 57,804 & 51 & 10,012 & 86 & 10,029 & 94.1 \\
\hline 2008 & 60,224 & 63 & 9,992 & 91 & 11,359 & 96.8 \\
\hline 2009 & 62,712 & 74 & 8,262 & 61 & 12,707 & 78.9 \\
\hline 2010 & 70,328 & 89 & 9,204 & 77 & 12,773 & 105.3 \\
\hline 2011 & 77,720 & 107 & 9,117 & 88 & 12,844 & 129.0 \\
\hline Average Share & $69 \%$ & $22 \%$ & $16 \%$ & $33 \%$ & $15 \%$ & $45 \%$ \\
\hline \multirow[b]{2}{*}{ Year } & \multicolumn{6}{|c|}{ Panel B: Importers } \\
\hline & $\begin{array}{l}\text { Total Number } \\
\text { of Ordinary } \\
\text { Trade Firms }\end{array}$ & $\begin{array}{l}\text { Total Exports by } \\
\text { Ordinary Trade Firms } \\
\text { (billions of USD) }\end{array}$ & $\begin{array}{l}\text { Total Number } \\
\text { of Pure } \\
\text { Processing } \\
\text { Trade Firms }\end{array}$ & $\begin{array}{l}\text { Total Exports by } \\
\text { Pure Processing } \\
\text { Trade Firms } \\
\text { (billions of USD) }\end{array}$ & $\begin{array}{l}\text { Total Number } \\
\text { of Mixed } \\
\text { Trade Firms }\end{array}$ & $\begin{array}{l}\text { Total Exports by } \\
\text { Mixed Trade Firms } \\
\text { (billions of USD) }\end{array}$ \\
\hline 2000 & 6,946 & 5 & 10,126 & 3 & 3,378 & 13.9 \\
\hline 2001 & 8,057 & 7 & 9,591 & 4 & 3,493 & 18.4 \\
\hline 2002 & 9,958 & 6 & 10,344 & 4 & 4,062 & 17.0 \\
\hline 2003 & 12,719 & 8 & 11,050 & 6 & 4,933 & 20.6 \\
\hline 2004 & 15,582 & 10 & 12,428 & 8 & 5,523 & 26.6 \\
\hline 2005 & 17,656 & 12 & 13,141 & 9 & 6,127 & 27.8 \\
\hline 2006 & 19,475 & 13 & 13,514 & 10 & 6,639 & 35.3 \\
\hline 2007 & 19,557 & 16 & 12,909 & 11 & 4,524 & 42.0 \\
\hline 2008 & 20,815 & 19 & 12,653 & 13 & 5,534 & 48.8 \\
\hline 2009 & 21,603 & 11 & 12,070 & 9 & 5,118 & 57.0 \\
\hline 2010 & 23,521 & 20 & 12,842 & 14 & 5,969 & 68.0 \\
\hline 2011 & 24,826 & 24 & 13,598 & 16 & 6,211 & 82.2 \\
\hline Average Share & $48 \%$ & $22 \%$ & $37 \%$ & $15 \%$ & $15 \%$ & $63 \%$ \\
\hline
\end{tabular}

Notes: Authors' calculation based on 2000-2011 Chinese Customs Data. 
Table 3: Firm Dynamics in China-US Trade

\begin{tabular}{|c|c|c|c|c|c|c|c|c|c|c|}
\hline \multirow[b]{2}{*}{ Year } & \multicolumn{3}{|c|}{ Continuing Firms } & \multicolumn{3}{|c|}{ Entry Firms } & \multicolumn{3}{|c|}{ Exit Firms } & \multirow{2}{*}{$\begin{array}{l}\text { All Firms } \\
\Delta \text { Export Value } \\
\text { (USD billion) }\end{array}$} \\
\hline & $\begin{array}{l}\text { Number } \\
\text { of Firms }\end{array}$ & $\begin{array}{l}\Delta \text { Export Value } \\
\text { (USD billion) }\end{array}$ & Share & $\begin{array}{l}\text { Number } \\
\text { of Firms }\end{array}$ & $\begin{array}{l}\Delta \text { Export Value } \\
\text { (USD billion) }\end{array}$ & Share & $\begin{array}{l}\text { Number } \\
\text { of Firms } \\
\end{array}$ & $\begin{array}{l}\Delta \text { Export Value } \\
\text { (USD billion) }\end{array}$ & Share & \\
\hline & \multicolumn{10}{|c|}{ Panel A: Exporters } \\
\hline $2000-2001$ & 18,045 & 5 & $73 \%$ & 8,127 & 4 & $51 \%$ & 5,393 & 2 & $23 \%$ & 7 \\
\hline 2001-2002 & 20,469 & 7 & $69 \%$ & 11,366 & 5 & $47 \%$ & 5,703 & 2 & $16 \%$ & 10 \\
\hline $2002-2003$ & 25,681 & 17 & $77 \%$ & 13,874 & 7 & $31 \%$ & 6,154 & 2 & $7 \%$ & 23 \\
\hline 2003-2004 & 31,498 & 25 & $77 \%$ & 18,380 & 10 & $30 \%$ & 8,057 & 2 & $7 \%$ & 32 \\
\hline 2004-2005 & 39,482 & 29 & $78 \%$ & 23,711 & 11 & $30 \%$ & 10,396 & 3 & $8 \%$ & 37 \\
\hline $2005-2006$ & 49,564 & 32 & $80 \%$ & 26,517 & 12 & $31 \%$ & 13,629 & 4 & $11 \%$ & 40 \\
\hline $2006-2007$ & 53,163 & 72 & $237 \%$ & 24,682 & 15 & $50 \%$ & 22,918 & 57 & $187 \%$ & 30 \\
\hline $2007-2008$ & 59,247 & 11 & $58 \%$ & 22,328 & 18 & $92 \%$ & 18,598 & 10 & $50 \%$ & 19 \\
\hline 2008-2009 & 60,574 & -37 & $101 \%$ & 23,107 & 16 & $-43 \%$ & 21,001 & 16 & $-42 \%$ & -37 \\
\hline $2009-2010$ & 65,245 & 44 & $76 \%$ & 27,060 & 24 & $41 \%$ & 18,436 & 10 & $17 \%$ & 58 \\
\hline $2010-2011$ & 73,046 & 38 & $72 \%$ & 26,635 & 29 & $54 \%$ & 19,259 & 14 & $26 \%$ & 53 \\
\hline \multirow[t]{2}{*}{ Average } & 45092 & 22 & $91 \%$ & 20526 & 14 & $38 \%$ & 13595 & 11 & $28 \%$ & 25 \\
\hline & \multicolumn{10}{|c|}{ Panel B: Importers } \\
\hline $2000-2001$ & 13,289 & 5 & $75 \%$ & 7,852 & 3 & $42 \%$ & 7,161 & 1 & $17 \%$ & 6 \\
\hline 2001-2002 & 14,155 & -3 & $163 \%$ & 10,209 & 2 & $-150 \%$ & 6,986 & 1 & $-88 \%$ & -2 \\
\hline $2002-2003$ & 16,662 & 4 & $66 \%$ & 12,040 & 4 & $57 \%$ & 7,702 & 2 & $22 \%$ & 7 \\
\hline 2003-2004 & 19,344 & 8 & $76 \%$ & 14,189 & 4 & $41 \%$ & 9,358 & 2 & $17 \%$ & 11 \\
\hline 2004-2005 & 22,257 & 3 & $78 \%$ & 14,667 & 4 & $105 \%$ & 11,276 & 3 & $84 \%$ & 4 \\
\hline $2005-2006$ & 24,641 & 8 & $80 \%$ & 14,987 & 5 & $50 \%$ & 12,283 & 3 & $30 \%$ & 10 \\
\hline $2006-2007$ & 22,481 & 14 & $125 \%$ & 14,509 & 6 & $55 \%$ & 17,147 & 9 & $80 \%$ & 11 \\
\hline $2007-2008$ & 23,734 & 8 & $71 \%$ & 15,268 & 8 & $65 \%$ & 13,256 & 4 & $36 \%$ & 12 \\
\hline $2008-2009$ & 24,256 & -5 & $137 \%$ & 14,535 & 7 & $-174 \%$ & 14,746 & 5 & $-137 \%$ & -4 \\
\hline $2009-2010$ & 26,129 & 16 & $67 \%$ & 16,203 & 13 & $53 \%$ & 12,662 & 5 & $20 \%$ & 25 \\
\hline $2010-2011$ & 28,633 & 11 & $53 \%$ & 16,002 & 15 & $75 \%$ & 13,699 & 6 & $28 \%$ & 20 \\
\hline Average & 21416 & 6 & $90 \%$ & 13678 & 6 & $20 \%$ & 11480 & 4 & $10 \%$ & 9 \\
\hline
\end{tabular}

Notes: Authors' calculation based on 2000-2011 Chinese Customs Data. 
Table 4: The CNY/USD Rate and Chinese Firm-Level Exports to and Imports from the US

\begin{tabular}{|c|c|c|c|c|c|}
\hline VARIABLES & All Firms & $\begin{array}{c}\text { Ordinary } \\
\text { Firms }\end{array}$ & $\begin{array}{c}\text { Mixed } \\
\text { Processing } \\
\text { Firms } \\
\end{array}$ & $\begin{array}{c}\text { Pure } \\
\text { Processing } \\
\text { Firms } \\
\end{array}$ & All Firms \\
\hline & \multicolumn{5}{|c|}{ Panel A: Exports to US } \\
\hline & $(1)$ & $(2)$ & (3) & (4) & $(5)$ \\
\hline $\ln (\mathrm{NER})$ & $\begin{array}{c}1.351 * * * \\
(0.325)\end{array}$ & $\begin{array}{c}3.092 * * * \\
(0.540)\end{array}$ & $\begin{array}{c}1.303 * * * \\
(0.413)\end{array}$ & $\begin{array}{c}1.145 \\
(0.995)\end{array}$ & $\begin{array}{c}1.385^{* * *} \\
(0.411)\end{array}$ \\
\hline $\ln (\mathrm{NER}) \times$ Share of Processing Trade & & & & & $\begin{array}{c}-0.852 * * * \\
(0.227)\end{array}$ \\
\hline $\ln (\mathrm{WER})$ & $\begin{array}{c}0.216 \\
(0.237)\end{array}$ & $\begin{array}{c}0.265 \\
(0.320)\end{array}$ & $\begin{array}{c}0.678 \\
(0.558)\end{array}$ & $\begin{array}{c}0.256 \\
(0.267)\end{array}$ & $\begin{array}{c}0.450 \\
(0.495)\end{array}$ \\
\hline $\ln \left(\mathrm{GDP}^{\mathrm{USA}}\right)$ & $\begin{array}{c}1.870 * * * \\
(0.411)\end{array}$ & $\begin{array}{c}1.085 * * * \\
(0.024)\end{array}$ & $\begin{array}{c}1.085 * * * \\
(0.324)\end{array}$ & $\begin{array}{c}1.381 * * * \\
(0.111)\end{array}$ & $\begin{array}{c}1.056 * * * \\
(0.010)\end{array}$ \\
\hline Observations & 496014 & 400535 & 55243 & 40236 & 496014 \\
\hline R-squared & 0.448 & 0.475 & 0.549 & 0.464 & 0.543 \\
\hline \multirow[t]{3}{*}{$\mathrm{Chi}^{2}$ Statistics } & & & $21.78 * * *$ & $19.77 * * *$ & \\
\hline & \multicolumn{5}{|c|}{ Panel B: Imports from US } \\
\hline & $\left(1^{\prime}\right)$ & $\left(2^{\prime}\right)$ & $\left(3^{\prime}\right)$ & $\left(4^{\prime}\right)$ & $\left(5^{\prime}\right)$ \\
\hline $\ln (\mathrm{NER})$ & $\begin{array}{c}-1.617 * * * \\
(0.429)\end{array}$ & $\begin{array}{c}-1.472 * * * \\
(0.315)\end{array}$ & $\begin{array}{c}-0.873 * * * \\
(0.203)\end{array}$ & $\begin{array}{l}-0.489 \\
(0.498)\end{array}$ & $\begin{array}{c}-1.579 * * * \\
(0.404)\end{array}$ \\
\hline $\ln (\mathrm{NER}) \times$ Share of Processing Trade & & & & & $\begin{array}{c}1.267 * * * \\
(0.428)\end{array}$ \\
\hline $\ln (\mathrm{WER})$ & $\begin{array}{c}0.120 \\
(0.137)\end{array}$ & $\begin{array}{c}0.197 \\
(0.270)\end{array}$ & $\begin{array}{c}0.325 \\
(0.465)\end{array}$ & $\begin{array}{c}0.233 \\
(0.247)\end{array}$ & $\begin{array}{c}0.256 \\
(0.375)\end{array}$ \\
\hline $\ln \left(\mathrm{GDP}^{\mathrm{CHN}}\right)$ & $\begin{array}{c}0.542 \\
(0.589)\end{array}$ & $\begin{array}{c}0.268 \\
(0.321)\end{array}$ & $\begin{array}{c}0.421 \\
(0.560)\end{array}$ & $\begin{array}{c}0.132 \\
(0.327)\end{array}$ & $\begin{array}{c}0.870 \\
(0.905)\end{array}$ \\
\hline Observations & 235581 & 128272 & 57533 & 49776 & 235581 \\
\hline R-squared & 0.357 & 0.515 & 0.501 & 0.525 & 0.545 \\
\hline $\mathrm{Chi}^{2}$ Statistics & & & $24.67 * * *$ & $25.12 * * *$ & \\
\hline
\end{tabular}

Notes: Dependent variable is the percentage change of Chinese firm $f$ 's exports to US or Chinese firm $f$ 's imports from US over year $t-1$ and $t$. OLS coefficients are reported with robust standard errors adjusted for clustering at the firm level. We also control for time trend, squared time trend, industry and firm fixed effects in all the regressions. ***, **, and * indicate statistical significance at the $1 \%, 5 \%$, and $10 \%$, respectively. $\mathrm{Chi}^{2}$ Statistics test the significant difference between the specified firm group and the group of ordinary firms. 
Table 5: The CNY/USD Rate and Chinese Firm-Level Entry into China-US Export and Import Markets

\begin{tabular}{|c|c|c|c|c|c|}
\hline VARIABLES & All Firms & $\begin{array}{c}\text { Ordinary } \\
\text { Firms }\end{array}$ & $\begin{array}{c}\text { Mixed } \\
\text { Processing } \\
\text { Firms }\end{array}$ & $\begin{array}{c}\text { Pure } \\
\text { Processing } \\
\text { Firms }\end{array}$ & All Firms \\
\hline & \multicolumn{5}{|c|}{ Panel A: Entry into Export Market } \\
\hline & $(1)$ & $(2)$ & (3) & (4) & $(5)$ \\
\hline $\ln (\mathrm{NER})$ & $\begin{array}{c}0.100 * * \\
(0.048)\end{array}$ & $\begin{array}{c}0.115 * * * \\
(0.013)\end{array}$ & $\begin{array}{c}0.102 * * * \\
(0.011)\end{array}$ & $\begin{array}{l}0.098^{*} \\
(0.055)\end{array}$ & $\begin{array}{c}0.089 * * \\
(0.042)\end{array}$ \\
\hline $\ln ($ NER $) \times$ Share of Processing Trade & & & & & $\begin{array}{c}-0.014 * * * \\
(0.004)\end{array}$ \\
\hline Observations & 721801 & 600312 & 62580 & 58909 & 721801 \\
\hline Pseudo R-squared & 0.379 & 0.612 & 0.429 & 0.454 & 0.311 \\
\hline \multirow[t]{3}{*}{$\mathrm{Chi}^{2}$ Statistics } & & & $19.93 * * *$ & $20.21 * * *$ & \\
\hline & \multicolumn{5}{|c|}{ Panel B: Entry into Import Market } \\
\hline & $\left(1^{\prime}\right)$ & $\left(2^{\prime}\right)$ & $\left(3^{\prime}\right)$ & $\left(4^{\prime}\right)$ & $\left(5^{\prime}\right)$ \\
\hline $\ln (\mathrm{NER})$ & $\begin{array}{l}-0.115^{*} \\
(0.065)\end{array}$ & $\begin{array}{c}-0.185^{* *} \\
(0.088)\end{array}$ & $\begin{array}{c}-0.130^{* * *} \\
(0.034)\end{array}$ & $\begin{array}{l}-0.086^{*} \\
(0.054)\end{array}$ & $\begin{array}{c}-0.069 * * * \\
(0.020)\end{array}$ \\
\hline $\ln ($ NER $) \times$ Share of Processing Trade & & & & & $\begin{array}{c}0.023 * * * \\
(0.006)\end{array}$ \\
\hline Observations & 386042 & 219164 & 67619 & 99259 & 386042 \\
\hline Pseudo R-squared & 0.278 & 0.511 & 0.328 & 0.353 & 0.319 \\
\hline $\mathrm{Chi}^{2}$ Statistics & & & $18.93 * * *$ & $20.67 * * *$ & \\
\hline
\end{tabular}

Notes: Dependent variable is an indicator of firm $f$ 's entry into exporting from China to US during year $t-l$ and $t$ or entry into importing from US to China during year $t-l$ and $t$. Marginal effects of probit regressions are reported with robust standard errors adjusted for clustering at the industry level. We also control for weighted exchange rate between RMB and the currencies of other major trading partners, US GDP or Chinese GDP, time trend, squared time trend, industry fixed effects in the regressions. $* * *, * *$, and $*$ indicate statistical significance at the $1 \%, 5 \%$, and $10 \%$, respectively. $\mathrm{Chi}^{2}$ Statistics test the significant difference between the specified firm group and the group of ordinary firms. 
Table 6: The CNY/USD Rate and Firm-Level Exit from China-US Export and Import Markets

\begin{tabular}{|c|c|c|c|c|c|}
\hline VARIABLES & All Firms & $\begin{array}{c}\text { Ordinary } \\
\text { Firms }\end{array}$ & $\begin{array}{c}\text { Mixed } \\
\text { Processing } \\
\text { Firms }\end{array}$ & $\begin{array}{c}\text { Pure } \\
\text { Processing } \\
\text { Firms }\end{array}$ & All Firms \\
\hline & \multicolumn{5}{|c|}{ Panel A: Exit from Export Market } \\
\hline & $(1)$ & (2) & (3) & (4) & (5) \\
\hline $\ln (\mathrm{NER})$ & $\begin{array}{c}-0.169 * * * \\
(0.051)\end{array}$ & $\begin{array}{c}-0.492^{* * *} \\
(0.139)\end{array}$ & $\begin{array}{c}-0.432 * * * \\
(0.134)\end{array}$ & $\begin{array}{l}-0.154 \\
(0.142)\end{array}$ & $\begin{array}{c}-0.203 * * * \\
(0.061)\end{array}$ \\
\hline $\ln (\mathrm{NER}) \times$ Share of Processing Trade & & & & & $\begin{array}{c}0.068 * * * \\
(0.019)\end{array}$ \\
\hline Observations & 657954 & 544802 & 61726 & 51426 & 657954 \\
\hline Pseudo R-squared & 0.401 & 0.634 & 0.451 & 0.476 & 0.287 \\
\hline \multirow[t]{3}{*}{$\mathrm{Chi}^{2}$ Statistics } & & & $20.56 * * *$ & $21.45 * * *$ & \\
\hline & \multicolumn{5}{|c|}{ Panel B: Exit from Import Market } \\
\hline & $\left(1^{\prime}\right)$ & $\left(2^{\prime}\right)$ & $\left(3^{\prime}\right)$ & $\left(4^{\prime}\right)$ & $\left(5^{\prime}\right)$ \\
\hline $\ln (\mathrm{NER})$ & $\begin{array}{c}0.101 * * \\
(0.048)\end{array}$ & $\begin{array}{c}0.162 * * * \\
(0.052)\end{array}$ & $\begin{array}{c}0.136 * * \\
(0.065)\end{array}$ & $\begin{array}{c}0.021 \\
(0.031)\end{array}$ & $\begin{array}{c}0.094 * * * \\
(0.030)\end{array}$ \\
\hline $\ln (\mathrm{NER}) \times$ Share of Processing Trade & & & & & $\begin{array}{c}-0.068 * * * \\
(0.022)\end{array}$ \\
\hline Observations & 317029 & 180721 & 65660 & 70648 & 317029 \\
\hline Pseudo R-squared & 0.427 & 0.425 & 0.394 & 0.349 & 0.382 \\
\hline $\mathrm{Chi}^{2}$ Statistics & & & $23.46 * * *$ & $22.16 * * *$ & \\
\hline
\end{tabular}

Notes: Dependent variable is an indicator of firm $f$ 's exit from exporting from China to US during year $t$ - 1 and $t$ or exit from importing from US to China during year $t-1$ and $t$. Marginal effects of probit regressions are reported with robust standard errors adjusted for clustering at the industry level. We also control for weighted exchange rate between RMB and the currencies of other major trading partners, US GDP or Chinese GDP, time trend, squared time trend, industry fixed effects in the regressions. $* * * * *$, and $*$ indicate statistical significance at the $1 \%, 5 \%$, and $10 \%$, respectively. Chi ${ }^{2}$ Statistics test the significant difference between the specified firm group and the group of ordinary firms. 
Table 7: Economic Trade Balance Effect of 10\% CNY Appreciation

\begin{tabular}{|c|c|c|c|c|}
\hline & Continuing Firms & Entry Firms & Exit Firms & Total Change \\
\hline & \multicolumn{4}{|c|}{ Panel A: Homogeneous Firms } \\
\hline \multirow{2}{*}{$\Delta$ Exports } & -43.77 & -0.28 & 0.23 & -44.29 \\
\hline & $98.83 \%$ & $0.64 \%$ & $-0.53 \%$ & $100.00 \%$ \\
\hline \multirow[t]{2}{*}{$\Delta$ Imports } & 19.73 & 0.17 & -0.06 & 19.96 \\
\hline & $98.85 \%$ & $0.87 \%$ & $-0.28 \%$ & $100.00 \%$ \\
\hline \multirow[t]{3}{*}{$\Delta$ Trade Balance } & -24.05 & -0.11 & 0.18 & -24.33 \\
\hline & $98.81 \%$ & $0.46 \%$ & $-0.73 \%$ & $100.00 \%$ \\
\hline & \multicolumn{4}{|c|}{ Panel B: Ordinary, Mixed, and Pure Processing Firms } \\
\hline \multirow[t]{2}{*}{$\Delta$ Exports } & -84.35 & -0.32 & 0.49 & -85.16 \\
\hline & $99.05 \%$ & $0.38 \%$ & $-0.57 \%$ & $100.00 \%$ \\
\hline \multirow[t]{2}{*}{$\Delta$ Imports } & 14.49 & 0.29 & -0.27 & 15.05 \\
\hline & $96.30 \%$ & $1.92 \%$ & $-1.78 \%$ & $100.00 \%$ \\
\hline \multirow[t]{2}{*}{$\Delta$ Trade Balance } & -69.86 & -0.03 & 0.22 & -70.11 \\
\hline & $99.64 \%$ & $0.05 \%$ & $-0.31 \%$ & $100.00 \%$ \\
\hline
\end{tabular}

Notes: Author's calculation based on the regression results and 2011 Chinese Customs data. 
Table 8.1: Robustness Results - Real Exchange Rates

\begin{tabular}{|c|c|c|c|c|c|c|c|c|c|c|c|c|c|c|c|}
\hline VARIABLES & Firms & $\begin{array}{l}\text { Ordinary } \\
\text { Firms }\end{array}$ & $\begin{array}{c}\text { Mixed } \\
\text { Processing } \\
\text { Firms }\end{array}$ & $\begin{array}{c}\text { Pure } \\
\text { Processing } \\
\text { Firms }\end{array}$ & All Firms & All Firms & $\begin{array}{c}\text { Ordinary } \\
\text { Firms }\end{array}$ & $\begin{array}{c}\text { Mixed } \\
\text { Processing } \\
\text { Firms }\end{array}$ & $\begin{array}{c}\text { Pure } \\
\text { Processing } \\
\text { Firms }\end{array}$ & All Firms & All Firms & $\begin{array}{c}\text { Ordinary } \\
\text { Firms }\end{array}$ & $\begin{array}{c}\text { Mixed } \\
\text { Processing } \\
\text { Firms }\end{array}$ & $\begin{array}{c}\text { Pure } \\
\text { Processing } \\
\text { Firms }\end{array}$ & All Firms \\
\hline & \multicolumn{5}{|c|}{ Panel A: Exports to US } & \multicolumn{5}{|c|}{ Panel A': Entry into Exporting to US } & \multicolumn{5}{|c|}{ Panel A": Exit from Exporting to US } \\
\hline & \multicolumn{10}{|c|}{ Robustness: CPI adjusted real exchange rate } & \multirow{3}{*}{$\begin{array}{c}-0.194 * * * \\
(0.063)\end{array}$} & \multirow[b]{2}{*}{$\begin{array}{c}-0.715 * * * \\
(0.236)\end{array}$} & \multirow[b]{2}{*}{$\begin{array}{c}-0.290 * * * \\
\\
(0.083)\end{array}$} & \multirow[b]{2}{*}{$\begin{array}{c}-0.316 * * \\
(0.144)\end{array}$} & \multirow[b]{2}{*}{$\begin{array}{c}-0.315^{* * *} \\
(0.102)\end{array}$} \\
\hline $\ln \left(\mathrm{RER}^{\mathrm{CPI}}\right)$ & $\begin{array}{c}2.520 * * * \\
(0.646)\end{array}$ & $\begin{array}{c}3.127 * * * \\
(0.736)\end{array}$ & $\begin{array}{c}2.102 * * * \\
(0.421)\end{array}$ & $\begin{array}{c}0.504 \\
(0.489)\end{array}$ & $\begin{array}{c}2.429 * * * \\
(0.804)\end{array}$ & $\begin{array}{c}0.175^{* * *} \\
(0.025)\end{array}$ & $\begin{array}{c}0.157^{* * * *} \\
(0.020)\end{array}$ & $\begin{array}{c}0.141^{* * * *} \\
(0.017)\end{array}$ & $\begin{array}{c}0.108 \\
(0.113)\end{array}$ & $\begin{array}{c}0.112 * * * \\
(0.030)\end{array}$ & & & & & \\
\hline $\ln \left(\mathrm{RER}^{\mathrm{CPI}}\right) \times \mathrm{PT}$ & & & & & $\begin{array}{c}-0.516^{* * * *} \\
(0.165)\end{array}$ & & & & & $\begin{array}{c}-0.028^{* * * *} \\
(0.007)\end{array}$ & & & & & $\begin{array}{c}0.094 * * * \\
(0.019)\end{array}$ \\
\hline R-squared & 0.525 & 0.459 & 0.502 & 0.551 & 0.452 & 0.469 & 0.367 & 0.518 & 0.432 & 0.416 & 0.491 & 0.389 & 0.602 & 0.454 & 0.325 \\
\hline Observations & 496014 & 400535 & 55243 & 40236 & 496014 & 721801 & 600312 & 62580 & 58909 & 721801 & 657954 & 544802 & 61726 & 51426 & 657954 \\
\hline $\mathrm{Chi}^{2}$ Statistics & & & $23.67 * * *$ & $23.15^{* * *}$ & & & & $21.16^{* * * *}$ & $24.35^{* * *}$ & & & & $25.16^{* * *}$ & $25.10^{* * *}$ & \\
\hline \multicolumn{16}{|c|}{ Robustness: UCL adjusted real exchange rate } \\
\hline $\ln \left(\mathrm{RER}^{\mathrm{ULC}}\right)$ & $\begin{array}{c}2.158^{* * *} * \\
(0.532)\end{array}$ & $\begin{array}{c}3.273 * * * \\
(0.832)\end{array}$ & $\begin{array}{c}1.424 * * * \\
(0.432)\end{array}$ & $\begin{array}{l}0.804 * \\
(0.447)\end{array}$ & $\begin{array}{c}2.372^{* * * *} \\
(0.421)\end{array}$ & $\begin{array}{c}0.126 * * * \\
(0.016)\end{array}$ & $\begin{array}{c}0.181 * * * \\
(0.018)\end{array}$ & $\begin{array}{c}0.129 * * * \\
(0.015)\end{array}$ & $\begin{array}{l}0.107 * \\
(0.059)\end{array}$ & $\begin{array}{c}0.116 * * * \\
(0.023)\end{array}$ & $\begin{array}{c}-0.183^{* * * *} \\
(0.059)\end{array}$ & $\begin{array}{c}-0.678 * * * \\
(0.220)\end{array}$ & $\begin{array}{c}-0.486 \text { *** } \\
(0.139)\end{array}$ & $\begin{array}{l}-0.364 * \\
(0.205)\end{array}$ & $\begin{array}{c}-0.302 * * * \\
(0.095)\end{array}$ \\
\hline $\ln \left(\mathrm{RER}^{\mathrm{ULC}}\right) \times \mathrm{PT}$ & & & & & $\begin{array}{c}-0.710^{* * * *} \\
(0.150)\end{array}$ & & & & & $\begin{array}{c}-0.027 \text { **** } \\
(0.007)\end{array}$ & & & & & $\begin{array}{l}0.168^{*} \\
(0.094)\end{array}$ \\
\hline R-squared & 0.485 & 0.473 & 0.532 & 0.568 & 0.438 & 0.457 & 0.443 & 0.351 & 0.569 & 0.334 & 0.479 & 0.465 & 0.373 & 0.591 & 0.321 \\
\hline Observations & 496014 & 400535 & 55243 & 40236 & 496014 & 721801 & 600312 & 62580 & 58909 & 721801 & 657954 & 544802 & 61726 & 51426 & 657954 \\
\hline & \multicolumn{5}{|c|}{ Panel B: Imports from US } & \multicolumn{5}{|c|}{ Panel B': Entry into Importing from US } & \multicolumn{5}{|c|}{ Panel B": Exit from Importing from US } \\
\hline \multicolumn{16}{|c|}{ Robustness: CPI adjusted real exchange rate } \\
\hline $\ln \left(\mathrm{RER}^{\mathrm{CPI}}\right)$ & $\begin{array}{c}-1.675^{* * * *} \\
(0.416)\end{array}$ & $\begin{array}{c}-2.847 * * * \\
(0.562)\end{array}$ & $\begin{array}{c}-2.480 * * * \\
(0.579)\end{array}$ & $\begin{array}{l}-0.976 \\
(0.945)\end{array}$ & $\begin{array}{c}-1.674 * * * \\
(0.450)\end{array}$ & $\begin{array}{c}-0.236^{* * * *} \\
(0.080)\end{array}$ & $\begin{array}{c}-0.200^{* * * *} \\
(0.056)\end{array}$ & $\begin{array}{c}-0.141 * * * \\
(0.043)\end{array}$ & $\begin{array}{l}-0.075 \\
(0.136)\end{array}$ & $\begin{array}{c}-0.149 * * * \\
(0.048)\end{array}$ & $\begin{array}{c}0.217 * * * \\
(0.025)\end{array}$ & $\begin{array}{c}0.218 * * * \\
(0.068)\end{array}$ & $\begin{array}{l}0.132 * * \\
(0.063)\end{array}$ & $\begin{array}{c}0.079 \\
(0.123)\end{array}$ & $\begin{array}{c}0.203^{* * * *} \\
(0.056)\end{array}$ \\
\hline $\ln \left(\mathrm{RER}^{\mathrm{CPI}}\right) \times \mathrm{PT}$ & & & & & $\begin{array}{c}1.126 * * * \\
(0.352)\end{array}$ & & & & & $\begin{array}{c}0.054 * * \\
(0.026)\end{array}$ & & & & & $\begin{array}{c}-0.118 * * * \\
(0.038)\end{array}$ \\
\hline R-squared & 0.575 & 0.439 & 0.622 & 0.479 & 0.551 & 0.368 & 0.266 & 0.479 & 0.331 & 0.293 & 0.535 & 0.513 & 0.394 & 0.582 & 0.356 \\
\hline Observations & 235581 & 128272 & 57533 & 49776 & 235581 & 386042 & 219164 & 67619 & 99259 & 386042 & 317029 & 180721 & 65660 & 70648 & 317029 \\
\hline $\mathrm{Chi}^{2}$ Statistics & & & $23.37 * * *$ & $22.65^{* * * *}$ & & & & $22.57 * * *$ & $23.07 * * *$ & & & & $23.17 * * *$ & $22.26^{* * * *}$ & \\
\hline \multicolumn{16}{|c|}{ Robustness: UCL adjusted real exchange rate } \\
\hline $\ln \left(\mathrm{RER}^{\mathrm{ULC}}\right)$ & $\begin{array}{c}-1.669 * * * \\
(0.483)\end{array}$ & $\begin{array}{c}-2.236 * * \\
(0.972)\end{array}$ & $\begin{array}{c}-1.657 * * * \\
(0.580)\end{array}$ & $\begin{array}{l}-0.602 \\
(0.598)\end{array}$ & $\begin{array}{c}-1.685^{* * *} \\
(0.470)\end{array}$ & $\begin{array}{c}-0.169^{* * *} \\
(0.042)\end{array}$ & $\begin{array}{c}-0.214 * * \\
(0.102)\end{array}$ & $\begin{array}{c}-0.143 * * * \\
(0.045)\end{array}$ & $\begin{array}{l}-0.071 * \\
(0.039)\end{array}$ & $\begin{array}{c}-0.159 * * * \\
(0.052)\end{array}$ & $\begin{array}{c}0.185^{* * *} \\
(0.058)\end{array}$ & $\begin{array}{c}0.211 * * * \\
(0.070)\end{array}$ & $\begin{array}{c}0.143 * * \\
(0.068)\end{array}$ & $\begin{array}{c}0.119 \\
(0.213)\end{array}$ & $\begin{array}{c}0.184 * * * * \\
(0.060)\end{array}$ \\
\hline $\ln \left(\mathrm{RER}^{\mathrm{ULC}}\right) \times \mathrm{PT}$ & & & & & $\begin{array}{c}1.103 * * * \\
(0.335)\end{array}$ & & & & & $\begin{array}{c}0.073 * * * \\
(0.018)\end{array}$ & & & & & $\begin{array}{c}-0.112 * * * \\
(0.036)\end{array}$ \\
\hline R-squared & 0.492 & 0.513 & 0.421 & 0.602 & 0.558 & 0.356 & 0.342 & 0.254 & 0.468 & 0.261 & 0.414 & 0.366 & 0.393 & 0.391 & 0.315 \\
\hline Observations & 235581 & 128272 & 57533 & 49776 & 235581 & 386042 & 219164 & 67619 & 99259 & 386042 & 317029 & 180721 & 65660 & 70648 & 317029 \\
\hline $\mathrm{Chi}^{2}$ Statistics & & & $24.34 * * *$ & $25.67 * * *$ & & & & $25.23^{* * *}$ & $23.21 * * *$ & & & & $24.26 * * *$ & $25.17 * * *$ & \\
\hline
\end{tabular}

Notes: In Panel A and B, the dependent variable is the percentage change of Chinese firm $f$ 's exports to US or Chinese firm $f$ 's imports from US over year $t$ - 1 and $t$. OLS coefficients are reported with robust standard errors adjusted for clustering at the firm level. We also control for weighted exchange rate between RMB and the currencies of other major trading partners, US GDP or Chinese GDP, time trend, squared time trend, industry and firm fixed effects in all the regressions. In Panel A' and B', the dependent variable is an indicator of firm $f$ 's entry into exporting from China to US or entry into importing from US to China during year $t-1$ and $t$. In Panel A" and B", the dependent variable is an indicator of firm f's exit from exporting from China to US or exit from importing from US to China during year $t-1$ and $t$. Marginal effects of probit regressions are reported with robust standard errors adjusted for clustering at the industry level. We also control for weighted exchange rate between RMB and the currencies of other major trading partners, US GDP or Chinese GDP, time trend, squared time trend, industry fixed effects in the regressions.***, **, and * indicate statistical significance at the $1 \%, 5 \%$, and $10 \%$, respectively. Chi ${ }^{2}$ Statistics test the significant difference between the specified firm group and the group of ordinary firms. 
Table 8.2: Robustness Results - Alternative Processing Firm Definitions

\begin{tabular}{|c|c|c|c|c|c|c|c|c|c|c|c|c|c|c|c|}
\hline VARIABLES & All Firms & $\begin{array}{l}\text { Ordinary } \\
\text { Firms }\end{array}$ & $\begin{array}{l}\text { Processing } \\
\text { Firms }\end{array}$ & $\begin{array}{c}\text { Low } \\
\text { Processing } \\
\text { Firms }\end{array}$ & $\begin{array}{l}\text { High } \\
\text { Processing } \\
\text { Firms }\end{array}$ & All Firms & $\begin{array}{l}\text { Ordinary } \\
\text { Firms }\end{array}$ & $\begin{array}{l}\text { Processing } \\
\text { Firms }\end{array}$ & $\begin{array}{c}\text { Low } \\
\text { Processing } \\
\text { Firms }\end{array}$ & $\begin{array}{c}\text { High } \\
\text { Processing } \\
\text { Firms }\end{array}$ & All Firms & $\begin{array}{c}\text { Ordinary } \\
\text { Firms }\end{array}$ & $\begin{array}{l}\text { Processing } \\
\text { Firms }\end{array}$ & $\begin{array}{c}\text { Low } \\
\text { Processing } \\
\text { Firms }\end{array}$ & $\begin{array}{c}\text { High } \\
\text { Processing } \\
\text { Firms }\end{array}$ \\
\hline & \multicolumn{5}{|c|}{ Panel A: Exports to US } & \multicolumn{5}{|c|}{ Panel A': Entry into Exporting to US } & \multicolumn{5}{|c|}{ Panel A": Exit from Exporting to US } \\
\hline Dln(NER) & $\begin{array}{c}1.351^{* * * *} \\
(0.325)\end{array}$ & $\begin{array}{c}3.092 * * * \\
(0.540)\end{array}$ & $\begin{array}{c}1.763^{* * *} * \\
(0.420)\end{array}$ & $\begin{array}{c}2.380 * * * \\
(0.529)\end{array}$ & $\begin{array}{c}1.082 \\
(0.951)\end{array}$ & $\begin{array}{c}0.100 * * \\
(0.048)\end{array}$ & $\begin{array}{c}0.115 * * * \\
(0.013)\end{array}$ & $\begin{array}{c}0.102 * * * \\
(0.011)\end{array}$ & $\begin{array}{c}0.085 * * * \\
(0.009)\end{array}$ & $\begin{array}{l}0.090 * * \\
(0.043)\end{array}$ & $\begin{array}{c}-0.169 * * * \\
(0.051)\end{array}$ & $\begin{array}{c}-0.492 * * * \\
(0.139)\end{array}$ & $\begin{array}{c}-0.395 * * * \\
(0.130)\end{array}$ & $\begin{array}{c}-0.412 * * \\
(0.196)\end{array}$ & $\begin{array}{l}-0.129 \\
(0.113)\end{array}$ \\
\hline Observations & 496014 & 400535 & 95479 & 29481 & 65998 & 721801 & 600312 & 121489 & 33099 & 88390 & 657954 & 544802 & 113152 & 32683 & 80469 \\
\hline R-squared & 0.448 & 0.475 & 0.477 & 0.55 & 0.532 & 0.379 & 0.612 & 0.428 & 0.369 & 0.395 & 0.401 & 0.634 & 0.421 & 0.391 & 0.417 \\
\hline \multirow[t]{2}{*}{$\mathrm{Chi}^{2}$ Statistics } & & & $20.16^{* * * *}$ & $22.56^{* * * *}$ & $23.57 * * *$ & & & $19.93 * * *$ & $22.76^{* * * *}$ & $21.72 * * *$ & & & $21.67 * * *$ & $23.16^{* * *}$ & $22.74 * * *$ \\
\hline & \multicolumn{5}{|c|}{ Panel B: Imports from US } & \multicolumn{5}{|c|}{ Panel B': Entry into Importing from US } & \multicolumn{5}{|c|}{ Panel B": Exit from Importing from US } \\
\hline $\operatorname{Dln}(\mathrm{NER})$ & $\begin{array}{c}-1.617 * * * \\
(0.429)\end{array}$ & $\begin{array}{c}-1.472 * * * \\
(0.315)\end{array}$ & $\begin{array}{c}-0.794 * * * \\
(0.270)\end{array}$ & $\begin{array}{c}-1.117 * * * \\
(0.311)\end{array}$ & $\begin{array}{l}-0.456 \\
(0.604)\end{array}$ & $\begin{array}{l}-0.115^{*} \\
(0.065)\end{array}$ & $\begin{array}{c}-0.185^{* *} \\
(0.088)\end{array}$ & $\begin{array}{c}-0.112 * * * \\
(0.031)\end{array}$ & $\begin{array}{c}-0.121 * * * \\
(0.024)\end{array}$ & $\begin{array}{l}-0.089 \\
(0.109)\end{array}$ & $\begin{array}{c}0.101 * * \\
(0.048)\end{array}$ & $\begin{array}{c}0.162 * * * \\
(0.052)\end{array}$ & $\begin{array}{c}0.084 * * * \\
(0.018)\end{array}$ & $\begin{array}{c}0.091 * * * \\
(0.012)\end{array}$ & $\begin{array}{c}0.037 \\
(0.052)\end{array}$ \\
\hline Observations & 235581 & 128272 & 107309 & 36979 & 70330 & 386042 & 219164 & 166878 & 42561 & 124317 & 317029 & 180721 & 136308 & 41576 & 94732 \\
\hline R-squared & 0.357 & 0.515 & 0.475 & 0.439 & 0.476 & 0.278 & 0.511 & 0.327 & 0.268 & 0.294 & 0.427 & 0.425 & 0.459 & 0.271 & 0.294 \\
\hline $\mathrm{Chi}^{2}$ Statistics & & & $24.57 * * *$ & $22.12 * * *$ & $23.06 * * *$ & & & $21.39 * * *$ & $20.70 * * *$ & $22.63 * * *$ & & & $22.53 * * *$ & $22.28 * * *$ & $21.20 * * *$ \\
\hline
\end{tabular}

Notes: In Panel A and B, the dependent variable is the percentage change of Chinese firm $f$ 's exports to US or Chinese firm $f$ 's imports from US over year $t-1$ and $t$. OLS coefficients are reported with robust standard errors adjusted for clustering at the firm level. We also control for weighted exchange rate between RMB and the currencies of other major trading partners, US GDP or Chinese GDP, time trend, squared time trend, industry and firm fixed effects in all the regressions. In Panel A' and B', the dependent variable is an indicator of firm $f$ 's entry into exporting from China to US or entry into importing from US to China during year $t-1$ and $t$. In Panel A" and B", the dependent variable is an indicator of firm $f^{\prime}$ 's exit from exporting from China to US or exit from importing from US to China during year $t-1$ and $t$. Marginal effects of probit regressions are reported with robust standard errors adjusted for clustering at the industry level. We also control for weighted exchange rate between RMB and the currencies of other major trading partners, US GDP or Chinese GDP, time trend, squared time trend, industry fixed effects in the regressions.***,**, and * indicate statistical significance at the $1 \%, 5 \%$, and $10 \%$, respectively. Chi ${ }^{2}$ Statistics test the significant difference between the specified firm group and the group of ordinary firms. 
Table 8.3: Robustness Results - Lagged Exchange Rates

\begin{tabular}{|c|c|c|c|c|c|c|c|c|c|c|c|c|c|c|c|}
\hline VARIABLES & All Firms & $\begin{array}{c}\text { Ordinary } \\
\text { Firms }\end{array}$ & $\begin{array}{c}\text { Mixed } \\
\text { Processing } \\
\text { Firms }\end{array}$ & $\begin{array}{c}\text { Pure } \\
\text { Processing } \\
\text { Firms }\end{array}$ & All Firms & All Firms & $\begin{array}{c}\text { Ordinary } \\
\text { Firms }\end{array}$ & $\begin{array}{c}\text { Mixed } \\
\text { Processing } \\
\text { Firms }\end{array}$ & $\begin{array}{c}\text { Pure } \\
\text { Processing } \\
\text { Firms }\end{array}$ & All Firms & All Firms & $\begin{array}{c}\text { Ordinary } \\
\text { Firms }\end{array}$ & $\begin{array}{c}\text { Mixed } \\
\text { Processing } \\
\text { Firms }\end{array}$ & $\begin{array}{c}\text { Pure } \\
\text { Processing } \\
\text { Firms }\end{array}$ & All Firms \\
\hline & \multicolumn{5}{|c|}{ Panel A: Exports to US } & \multicolumn{5}{|c|}{ Panel A': Entry into Exporting to US } & \multicolumn{5}{|c|}{ Panel A": Exit from Exporting to US } \\
\hline \multicolumn{16}{|c|}{ Robustness: Using 1-year lagged exchange rate } \\
\hline$\Delta \ln (\mathrm{NER})$ & $\begin{array}{c}1.423 * * * \\
(0.431)\end{array}$ & $\begin{array}{c}3.215^{* * *} \\
(0.612)\end{array}$ & $\begin{array}{c}1.321 * * * \\
(0.476)\end{array}$ & $\begin{array}{c}1.104 \\
(1.216)\end{array}$ & $\begin{array}{c}1.442 * * * \\
(0.402)\end{array}$ & $\begin{array}{c}0.123 * * * \\
(0.022)\end{array}$ & $\begin{array}{c}0.134 * * * \\
(0.043)\end{array}$ & $\begin{array}{c}0.121^{* * * *} \\
(0.032)\end{array}$ & $\begin{array}{c}0.081 * * \\
(0.039)\end{array}$ & $\begin{array}{c}0.135^{* * * *} \\
(0.040)\end{array}$ & $\begin{array}{c}-0.220 * * * \\
(0.069)\end{array}$ & $\begin{array}{c}-0.494 * * * \\
\\
(0.150)\end{array}$ & $\begin{array}{c}-0.433 * * * \\
(0.142)\end{array}$ & $\begin{array}{l}-0.156 \\
(0.172)\end{array}$ & $\begin{array}{c}-0.205^{* * * *} \\
(0.052)\end{array}$ \\
\hline$\Delta \ln (\mathrm{NER}) \times \mathrm{PT}$ & & & & & $\begin{array}{c}-0.520^{* * * *} \\
(0.113)\end{array}$ & & & & & $\begin{array}{c}-0.015^{* * * *} \\
(0.003)\end{array}$ & & & & & $\begin{array}{c}0.062^{* * * *} \\
(0.021)\end{array}$ \\
\hline R-squared & 0.518 & 0.336 & 0.426 & 0.414 & 0.457 & 0.746 & 0.361 & 0.369 & 0.293 & 0.315 & 0.768 & 0.354 & 0.399 & 0.387 & 0.362 \\
\hline Observations & 477969 & 385964 & 53233 & 38772 & 477969 & 483617 & 402218 & 41929 & 39470 & 483617 & 479873 & 397347 & 45019 & 37507 & 479873 \\
\hline $\mathrm{Chi}^{2}$ Statistics & & & $22.83^{* * *}$ & $22.52 * * *$ & & & & $23.15^{* * *}$ & $23.54 * * *$ & & & & $24.76^{* * * *}$ & $24.72 * * *$ & \\
\hline \multicolumn{16}{|c|}{ Robustness: Using 2-year lagged exchange rate } \\
\hline$\Delta \ln (\mathrm{NER})$ & $\begin{array}{c}1.873 * * * \\
(0.560)\end{array}$ & $\begin{array}{c}3.174 * * * \\
(0.521)\end{array}$ & $\begin{array}{c}1.316^{* * * *} \\
(0.276)\end{array}$ & $\begin{array}{c}1.133 \\
(1.127)\end{array}$ & $\begin{array}{c}1.776^{* * *} \\
(0.326)\end{array}$ & $\begin{array}{c}0.140 * * * \\
(0.029)\end{array}$ & $\begin{array}{c}0.142 * * * \\
(0.047)\end{array}$ & $\begin{array}{c}0.125^{* * * *} \\
(0.042)\end{array}$ & $\begin{array}{l}0.084^{*} \\
(0.047)\end{array}$ & $\begin{array}{c}0.146 * * * \\
(0.043)\end{array}$ & $\begin{array}{c}-0.223^{* * * *} \\
(0.069)\end{array}$ & $\begin{array}{c}-0.490^{* * * *} \\
(0.148)\end{array}$ & $\begin{array}{c}-0.434 * * * * \\
(0.142)\end{array}$ & $\begin{array}{l}-0.161 \\
(0.231)\end{array}$ & $\begin{array}{c}-0.207 * * * * \\
(0.060)\end{array}$ \\
\hline$\Delta \ln (\mathrm{NER}) \times \mathrm{PT}$ & & & & & $\begin{array}{c}-0.518 * * * \\
(0.097)\end{array}$ & & & & & $\begin{array}{c}-0.019 * * * \\
(0.005)\end{array}$ & & & & & $\begin{array}{c}0.063^{* * *} * \\
(0.015)\end{array}$ \\
\hline R-squared & 0.509 & 0.471 & 0.492 & 0.554 & 0.425 & 0.717 & 0.522 & 0.361 & 0.425 & 0.464 & 0.739 & 0.292 & 0.321 & 0.328 & 0.431 \\
\hline Observations & 328029 & 264886 & 36534 & 26609 & 328029 & 347012 & 288605 & 30086 & 28321 & 347012 & 334585 & 277045 & 31389 & 26151 & 334585 \\
\hline & \multicolumn{5}{|c|}{ Panel B: Imports from US } & \multicolumn{5}{|c|}{ Panel B': Entry into Importing from US } & \multicolumn{5}{|c|}{ Panel B": Exit from Importing from US } \\
\hline & \multicolumn{10}{|c|}{ Robustness: Using 1-year lagged exchange rate } & & & & & \\
\hline$\Delta \ln (\mathrm{NER})$ & $\begin{array}{c}-1.720^{* * * *} \\
(0.519)\end{array}$ & $\begin{array}{c}-1.673^{* * * *} \\
(0.416)\end{array}$ & $\begin{array}{c}-0.810^{* * *} \\
(0.173)\end{array}$ & $\begin{array}{l}-0.429 \\
(0.472)\end{array}$ & $\begin{array}{c}-1.619^{* * * *} \\
(0.354)\end{array}$ & $\begin{array}{c}-0.243^{* * * *} \\
(0.079)\end{array}$ & $\begin{array}{c}-0.247 * * \\
(0.118)\end{array}$ & $\begin{array}{c}-0.176^{* * *} \\
(0.054)\end{array}$ & $\begin{array}{l}-0.097 \\
(0.120)\end{array}$ & $\begin{array}{c}-0.227 * * * * \\
(0.043)\end{array}$ & $\begin{array}{c}0.190^{* * * *} \\
(0.061)\end{array}$ & $\begin{array}{c}0.158 * * * \\
(0.026)\end{array}$ & $\begin{array}{c}0.144 * * * \\
(0.030)\end{array}$ & $\begin{array}{c}0.026 \\
(0.046)\end{array}$ & $\begin{array}{c}0.189^{* * * *} \\
(0.023)\end{array}$ \\
\hline$\Delta \ln (\mathrm{NER}) \times \mathrm{PT}$ & & & & & $\begin{array}{c}0.942^{* * *} \\
(0.216)\end{array}$ & & & & & $\begin{array}{c}0.020 * * * \\
(0.003)\end{array}$ & & & & & $\begin{array}{c}-0.058 * * * \\
(0.019)\end{array}$ \\
\hline R-squared & 0.524 & 0.382 & 0.497 & 0.422 & 0.304 & 0.645 & 0.411 & 0.263 & 0.162 & 0.499 & 0.365 & 0.316 & 0.346 & 0.353 & 0.378 \\
\hline Observations & 222292 & 121036 & 54288 & 46968 & 222292 & 239832 & 136158 & 42008 & 61666 & 239832 & 230721 & 131522 & 47784 & 51415 & 230721 \\
\hline $\mathrm{Chi}^{2}$ Statistics & & & $24.13^{* * *}$ & $24.56^{* * *}$ & & & & $24.36^{* * * *}$ & $24.57 * * *$ & & & & $24.60^{* * * *}$ & $25.15^{* * *}$ & \\
\hline \multicolumn{16}{|c|}{ Robustness: Using 2-year lagged exchange rate } \\
\hline$\Delta \ln (\mathrm{NER})$ & $\begin{array}{c}-1.773 * * * \\
(0.522)\end{array}$ & $\begin{array}{c}-1.594 * * * \\
(0.305)\end{array}$ & $\begin{array}{c}-0.856 * * * \\
(0.214)\end{array}$ & $\begin{array}{l}-0.413 \\
(0.422)\end{array}$ & $\begin{array}{c}-1.538^{* * * *} \\
(0.500)\end{array}$ & $\begin{array}{c}-0.376^{* * *} \\
(0.118)\end{array}$ & $\begin{array}{c}-0.242^{* * *} \\
(0.070)\end{array}$ & $\begin{array}{c}-0.181 * * * \\
(0.058)\end{array}$ & $\begin{array}{l}-0.101 \\
(0.135)\end{array}$ & $\begin{array}{c}-0.331 * * * \\
(0.019)\end{array}$ & $\begin{array}{c}0.213 * * * \\
(0.069)\end{array}$ & $\begin{array}{c}0.163 * * * \\
(0.023)\end{array}$ & $\begin{array}{c}0.147 * * * \\
(0.049)\end{array}$ & $\begin{array}{c}0.025 \\
(0.098)\end{array}$ & $\begin{array}{c}0.193 * * * \\
(0.021)\end{array}$ \\
\hline$\Delta \ln (\mathrm{NER}) \times \mathrm{PT}$ & & & & & $\begin{array}{c}1.031^{* * * *} \\
(0.258)\end{array}$ & & & & & $\begin{array}{c}0.013^{* * * *} \\
(0.003)\end{array}$ & & & & & $\begin{array}{c}-0.065 * * * \\
(0.020)\end{array}$ \\
\hline R-squared & 0.495 & 0.471 & 0.483 & 0.453 & 0.369 & 0.616 & 0.434 & 0.279 & 0.284 & 0.354 & 0.359 & 0.325 & 0.355 & 0.362 & 0.373 \\
\hline Observations & 146841 & 79954 & 35861 & 31026 & 146841 & 164332 & 93295 & 28784 & 42253 & 164332 & 152016 & 86656 & 31484 & 33876 & 152016 \\
\hline $\mathrm{Chi}^{2}$ Statistics & & & $25.32 * * *$ & $22.67 * * *$ & & & & $25.38 * * *$ & $26.34 * * *$ & & & & $22.17 * * *$ & $22.43^{* * * *}$ & \\
\hline
\end{tabular}

Notes: In Panel A and B, the dependent variable is the percentage change of Chinese firm $f$ 's exports to US or Chinese firm $f$ 's imports from US over year $t$ - 1 and $t$. OLS coefficients are reported with robust standard errors adjusted for clustering at the firm level. We also control for weighted exchange rate between RMB and the currencies of other major trading partners, US GDP or Chinese GDP, time trend, squared time trend, industry and firm fixed effects in all the regressions. In Panel A' and B', the dependent variable is an indicator of firm $f$ 's entry into exporting from China to US or entry into importing from US to China during year $t-1$ and $t$. In Panel A" and B", the dependent variable is an indicator of firm $f$ 's exit from exporting from China to US or exit from importing from US to China during year $t-l$ and $t$. Marginal effects of probit regressions are reported with robust standard errors adjusted for clustering at the industry level. We also control for weighted exchange rate between RMB and the currencies of other major trading partners, US GDP or Chinese GDP, time trend, squared time trend, industry fixed effects in the regressions.***, $* *$, and $*$ indicate statistical significance at the $1 \%, 5 \%$, and $10 \%$, respectively. Chi ${ }^{2}$ Statistics test the significant difference between the specified firm group and the group of ordinary firms. 
Table 8.4: Robustness Results - The 2006-2011 Sub-Sample Period

\begin{tabular}{|c|c|c|c|c|c|c|c|c|c|c|c|c|c|c|c|}
\hline VARIABLES & All Firms & $\begin{array}{l}\text { Ordinary } \\
\text { Firms }\end{array}$ & $\begin{array}{c}\text { Mixed } \\
\text { Processing } \\
\text { Firms }\end{array}$ & $\begin{array}{c}\text { Pure } \\
\text { Processing } \\
\text { Firms }\end{array}$ & All Firms & All Firms & $\begin{array}{l}\text { Ordinary } \\
\text { Firms }\end{array}$ & $\begin{array}{c}\text { Mixed } \\
\text { Processing } \\
\text { Firms }\end{array}$ & $\begin{array}{c}\text { Pure } \\
\text { Processing } \\
\text { Firms }\end{array}$ & All Firms & All Firms & $\begin{array}{c}\text { Ordinary } \\
\text { Firms }\end{array}$ & $\begin{array}{c}\text { Mixed } \\
\text { Processing } \\
\text { Firms }\end{array}$ & $\begin{array}{c}\text { Pure } \\
\text { Processing } \\
\text { Firms }\end{array}$ & All Firms \\
\hline & \multicolumn{5}{|c|}{ Panel A: Exports to US } & \multicolumn{5}{|c|}{ Panel A': Entry into Exporting to US } & \multicolumn{5}{|c|}{ Panel $A^{\prime \prime}$ : Exit from Exporting to US } \\
\hline$\Delta \ln (\mathrm{NER})$ & $\begin{array}{c}3.032 * * * \\
(0.617)\end{array}$ & $\begin{array}{c}3.216^{* * * *} \\
(0.728)\end{array}$ & $\begin{array}{c}3.005 * * * \\
(0.627)\end{array}$ & $\begin{array}{l}2.176^{*} \\
(1.222)\end{array}$ & $\begin{array}{c}3.002^{* * * *} \\
(0.936)\end{array}$ & $\begin{array}{c}0.100 * * \\
(0.048)\end{array}$ & $\begin{array}{c}0.150^{* * * *} \\
(0.016)\end{array}$ & $\begin{array}{c}0.134 * * * \\
(0.012)\end{array}$ & $\begin{array}{l}0.091^{* *} \\
(0.043)\end{array}$ & $\begin{array}{c}0.086^{* * * *} \\
(0.017)\end{array}$ & $\begin{array}{l}-0.178^{*} \\
(0.100)\end{array}$ & $\begin{array}{c}-0.509^{* *} \\
(0.242)\end{array}$ & $\begin{array}{l}-0.310^{*} \\
(0.174)\end{array}$ & $\begin{array}{l}-0.129 \\
(0.213)\end{array}$ & $\begin{array}{c}-0.214 * * * \\
(0.063)\end{array}$ \\
\hline$\Delta \ln (\mathrm{NER}) \times \mathrm{PT}$ & & & & & $\begin{array}{c}-0.878^{* *} \\
(0.418)\end{array}$ & & & & & $\begin{array}{c}-0.042 * * * \\
(0.013)\end{array}$ & & & & & $\begin{array}{c}0.121 * * * \\
(0.038)\end{array}$ \\
\hline R-squared & 0.485 & 0.437 & 0.515 & 0.533 & 0.528 & 0.597 & 0.354 & 0.435 & 0.378 & 0.621 & 0.619 & 0.376 & 0.457 & 0.382 & 0.732 \\
\hline Observations & 360839 & 321741 & 25135 & 13963 & 360839 & 511168 & 463127 & 28183 & 19858 & 511168 & 468800 & 424553 & 27634 & 16613 & 468800 \\
\hline \multirow[t]{2}{*}{$\mathrm{Chi}^{2}$ Statistics } & & & $23.46^{* * * *}$ & $25.12 * * *$ & & & & $24.70 * * *$ & $21.45^{* * *}$ & & & & $25.30 * * *$ & $26.57 * * *$ & \\
\hline & \multicolumn{5}{|c|}{ Panel B: Imports from US } & \multicolumn{5}{|c|}{ Panel B': Entry into Importing from US } & \multicolumn{5}{|c|}{ Panel B": Exit from Importing from US } \\
\hline$\Delta \ln (\mathrm{NER})$ & $\begin{array}{c}-3.359 * * * \\
(0.662)\end{array}$ & $\begin{array}{c}-2.268^{* * * *} \\
(0.516)\end{array}$ & $\begin{array}{c}-1.630^{* * *} \\
(0.556)\end{array}$ & $\begin{array}{c}-0.938 * * * \\
(0.242)\end{array}$ & $\begin{array}{c}-3.337 * * * \\
(0.628)\end{array}$ & $\begin{array}{c}-0.215^{* * *} \\
(0.059)\end{array}$ & $\begin{array}{c}-0.218 * * * \\
(0.070)\end{array}$ & $\begin{array}{c}-0.143 * * * \\
(0.042)\end{array}$ & $\begin{array}{l}-0.110 \\
(0.133)\end{array}$ & $\begin{array}{c}-0.168 * * * \\
(0.054)\end{array}$ & $\begin{array}{c}0.109 * * * \\
(0.035)\end{array}$ & $\begin{array}{c}0.253^{* * * *} \\
(0.082)\end{array}$ & $\begin{array}{c}0.178^{* *} \\
(0.085)\end{array}$ & $\begin{array}{c}0.037 * * \\
(0.018)\end{array}$ & $\begin{array}{c}0.112 * * * \\
(0.032)\end{array}$ \\
\hline$\Delta \ln (\mathrm{NER}) \times \mathrm{PT}$ & & & & & $\begin{array}{c}1.827 * * * \\
(0.505)\end{array}$ & & & & & $\begin{array}{c}0.051 * * * \\
(0.011)\end{array}$ & & & & & $\begin{array}{c}-0.079 * * * \\
(0.024)\end{array}$ \\
\hline R-squared & 0.447 & 0.425 & 0.482 & 0.415 & 0.583 & 0.496 & 0.253 & 0.334 & 0.277 & 0.243 & 0.373 & 0.457 & 0.589 & 0.443 & 0.337 \\
\hline Observations & 149874 & 93658 & 36865 & 19351 & 149874 & 241378 & 155192 & 43481 & 42705 & 241378 & 200129 & 130257 & 42037 & 27835 & 200129 \\
\hline $\mathrm{Chi}^{2}$ Statistics & & & $25.04 * * *$ & $25.17 * * *$ & & & & $23.17 * * *$ & $24.65^{* * * *}$ & & & & $23.11^{* * *} *$ & $24.51 * * *$ & \\
\hline
\end{tabular}

Notes: In Panel A and B, the dependent variable is the percentage change of Chinese firm $f$ 's exports to US or Chinese firm $f$ 's imports from US over year $t$ - 1 and $t$. OLS coefficients are reported with robus standard errors adjusted for clustering at the firm level. We also control for weighted exchange rate between RMB and the currencies of other major trading partners, US GDP or Chinese GDP, time trend, squared time trend, industry and firm fixed effects in all the regressions. In Panel A' and B', the dependent variable is an indicator of firm $f^{\prime}$ 's entry into exporting from China to US or entry into importing from US to China during year $t-1$ and $t$. In Panel A" and B", the dependent variable is an indicator of firm $f$ 's exit from exporting from China to US or exit from importing from US to China during year $t-1$ and $t$. Marginal effects of probit regressions are reported with robust standard errors adjusted for clustering at the industry level. We also control for weighted exchange rate between RMB and the currencies of other major trading partners,

US GDP or Chinese GDP, time trend, squared time trend, industry fixed effects in the regressions.***, **, and * indicate statistical significance at the $1 \%, 5 \%$, and $10 \%$, respectively. Chi ${ }^{2}$ Statistics test the significant difference between the specified firm group and the group of ordinary firms. 